\title{
Large-scale ecological patterns: discontinuous distribution of marine benthic epifauna*
}

\author{
P.-L. Ardisson**, E. Bourget*** \\ GIROQ, Département de biologie, Université Laval, Québec, Québec, Canada G1K 7P4
}

\begin{abstract}
Spatial distribution patterns of benthic littoral fauna were studied over a 12 yr period in a large subarctic ecosystem, the Estuary and northwestern Gulf of St. Lawrence. Binary presenceabsence data obtained from suspended collectors (navigation buoys) moored yearly, from May through November, were used to examine ecological affinities and spatial heterogeneity in species distribution. Analyses of species co-occurrence followed by arithmetic average clustering, conducted at large (whole system, Gulf, Estuary) and intermediate (North Shore plus Lower North Shore) spatial scales, revealed a recurrent species association (composed of 12 species including Obelia longissima, Mytilus edulis, Balanus crenatus, Hiatella arctica, and Semibalanus balanoides) characterizing the entire Estuary-Gulf area. Frequency analyses carried out along 3 potential pathways of larval dispersal made it possible to identify major spatial discontinuities in species distribution as well as the community members contributing most to them. The outstanding changes in composition and distribution of benthic species throughout the study area were highly coincident with well-defined physiographical (e.g. presence of straits, islands, contour of shoreline) and hydrographical (e.g. zones of freshwater inputs, upwellings, frontal zones) features of the system, particularly along the estuarine gradient.
\end{abstract}

\section{INTRODUCTION}

Littoral benthos distribution responds to 2 principal axes of variability, the vertical axis (e.g. influence of hydrological factors, water column stability, food supply, and behavioural patterns on zonation of species) and the horizontal axis (e.g. hydrodynamic control of larval migration and transport of adult individuals with horizontal distance), even though in nature, interactions of both axes are usually observed (Underwood \& Denley 1984, Mann 1986a, b, Possingham \& Roughgarden 1990). While distribution along the vertical axis has been thoroughly studied on shores (e.g. zonation studies), few studies have dealt with discontinuities along ecological gradients in highly variable environments such as estuaries and shelves, except in general terms (Southward 1967, Sanders

\footnotetext{
- Contribution to the program of GIROQ (Groupe Interuniversitaire de Recherches Océanographiques du Québec)

-Present address: Institut Maurice-Lamontagne. 850, route de la Mer C.P. 1000. Mont-Joli, Québec, Canada G5H $3 Z 4$ -.. Addressee for correspondence
}

1968, Kinne 1970, Wolff 1983). The present study, which is concerned only with the horizontal axis of variability, examines the composition and distribution of the littoral epibenthic community of a large subarctic ecosystem, the Estuary and northwestern Gulf of St. Lawrence. Our main objectives were (1) to determine the spatial affinities (co-occurrence) of species colonizing this area, (2) to characterize their distributional discontinuities, and (3) to identify the most relevant environmental factors responsible for these discontinuities. The size and physical heterogeneity of this system (see below) and collecting methods used allowed us to study the changes in composition and distribution of species under a large range of environmental conditions, in the absence of any direct influence of the vertical axis caused by the tidal emersion-immersion cycle.

Our focus was on benthic littoral species possessing planktonic larval stages, sampled on suspended collectors moored in open coastal waters within the surface 0 to $2 \mathrm{~m}$ depth layer. Therefore, discontinuities, such as observed here, are more likely to be associated with hydrodynamic singularities and physico-chemical 
characteristics of the water mass, rather than with topographic features of the bottom and shoreline. Furthermore, the limits of species distributions observed in this study may differ from those observed on shores. Thus, our approach should be viewed as a means of highlighting potential dispersal ranges rather than absolute limits of species distribution. Indeed, on shores, the environmental factors are certainly more constraining for survival and growth than those observed in the water column offshore.

\section{STUDY AREA}

The Estuary and Gulf of St. Lawrence is a coastal system located on the eastern seaboard of Canada, extending from about 46 to $52^{\circ} \mathrm{N}$ and from 56 to $73^{\circ} \mathrm{W}$ (Fig. 1A). It receives a large input of freshwater from the St. Lawrence River and other tributaries, and exchanges water, heat, and salt with the North Atlantic Ocean through 2 main openings: Cabot Strait and the Strait of Belle-Isle. The former is $104 \mathrm{~km}$ wide with a maximum depth of $480 \mathrm{~m}$. while the latter has a minimum width of $16 \mathrm{~km}$ and a sill depth of $60 \mathrm{~m}$ (Dickie \& Trites 1983).

On the basis of morphological and hydrographical characteristics (e.g. Brunel 1970, Neu 1970), the Estuary-Gulf system can be divided into 4 distinct regions (Fig. 1): (1) The Fluvial Estuary, the well-mixed freshwater portion of the St. Lawrence River under tidal influence, from Île d'Orléans up to Lake SaintPierre some $180 \mathrm{~km}$ upstream. (2) The Upper Estuary, from Île d'Orléans to the mouth of the Saguenay. Mixing of the freshwater outflow of the river with the saltwater intrusion is largely carried out in this portion of the system. This $150 \mathrm{~km}$ long region exceeds $50 \mathrm{~m}$ in depth only in few places. It is characterized by a seaward surface salinity gradient ranging from 0 to $25 \%$ (Lavoie 1970, Neu 1970), and a maximum turbidity zone located between Île d'Orléans and Île aux Coudres (Kranck 1979, Lucotte \& d'Anglejan 1986). Maximum summer surface temperatures $\left(20^{\circ} \mathrm{C}\right)$ are found near île d'Orléans, decreasing to $8^{\circ} \mathrm{C}$ downstream near the mouth of the Saguenay (Vigeant 1987). (3) The Lower Estuary from the Saguenay Fjord down to Pointe-des-Monts on the north shore and Les Méchins on the south shore. This $200 \mathrm{~km}$ long channel expands from a depth of less than $40 \mathrm{~m}$ and a width of $24 \mathrm{~km}$ at the western end to a depth of $340 \mathrm{~m}$ and $\mathrm{a}$ width of $46 \mathrm{~km}$ at the eastern end where it opens into the Gulf. This area is characterized by surface salinities varying from 24 to $30 \%$ and a pronounced stratification in summer. The summer temperatures of the surface layer vary from 4 to $12{ }^{\circ} \mathrm{C}$ with a more pronounced north-south than east-west gradient (El-
Sabh 1979, Vigeant 1987, Petrie 1990). (4) The Gulf, seaward from the Pointe-des-Monts-Les Méchins axis. One of the main bathymetric features of this region is the Laurentian Channel (with 2 branches, the Esquiman and the Anticosti Channels), with an average depth of $420 \mathrm{~m}$ and stretching over $1000 \mathrm{~km}$ from the Atlantic Ocean (through Cabot Strait) up to the head of the Lower Estuary. It is characterized by surface salinities varying from 27 to $32 \%$ and a 3 -layered summer temperature structure. The surface layer ranges in thickness from 10 to $30 \mathrm{~m}$ depending on the location and the month (Lauzier et al. 1957, Banks 1966). In the northwestern sector of the Gulf, the highest temperature values are observed in the Gaspé Peninsula

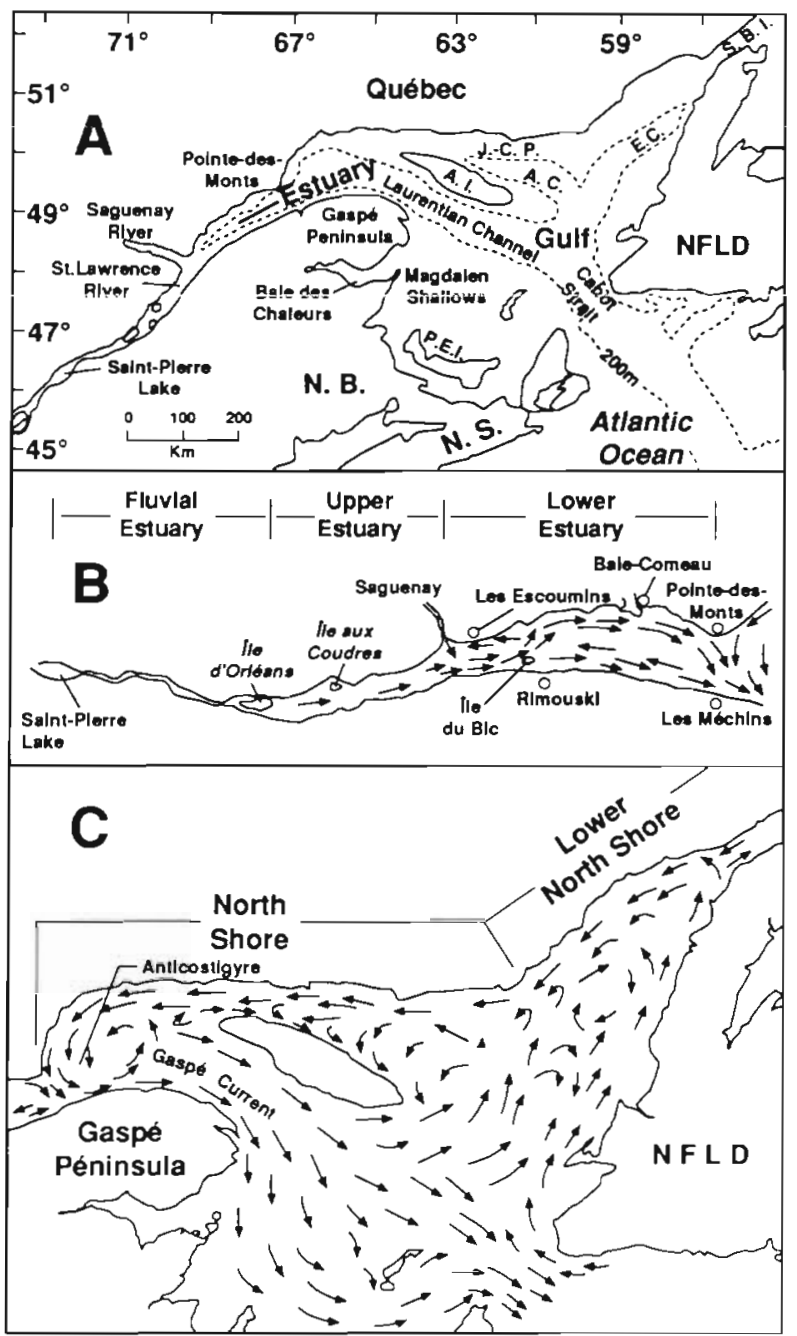

Fig. 1. The Estuary and Gulf of St. Lawrence. (A) Physiographic features; (B) summer surface circulation pattern in the Estuary (modified from El-Sabh 1977a); (C) summer surface circulation pattern in the Gulf (modified from El-Sabh 1976). S.B.I.. Strait of Belle-Isle; E.C.. Esquiman Channel; J.-C. P.: Jacques-Cartier Passage; A.C.. Anticosti Channel; A.I.. Anticosti Island 
region $\left(4\right.$ to $16^{\circ} \mathrm{C}$ ), intermediate values in both the western North Shore region $\left(2\right.$ to $15^{\circ} \mathrm{C}$ ) and the Jacques-Cartier Passage $\left(3\right.$ to $14^{\circ} \mathrm{C}$ ), and the lowest values in the Lower North Shore region $\left(1\right.$ to $\left.13^{\circ} \mathrm{C}\right)$ (Vigeant 1987, Petrie 1990).

Water motion in the study area is maintained by runoff and other forcing factors such as tides, winds, heat fluxes, and geostrophy. In the Upper Estuary, the circulation pattern is based on a 2-layer flow system in which the lower more saline layer flows upstream while the upper fresher layer flows seaward. Under the influence of topography and geostrophy, the lower flow is deflected towards the north and the upper flow towards the south shore. The seaward flow is reinforced at the head of the Lower Estuary by the brackish outflow of the Saguenay Fjord and continues until it reaches the (Île du) Bic-Rimouski region. Here, the buoyant flow divides in 2 branches. One flows along the south shore and gives rise to the Gaspé Current, a strong coastal jet flowing seaward along the Gaspé Peninsula (Benoit et al. 1985, Mertz et al. 1988). The other flows northward across the Estuary and then divides in 2 further branches: one turns to the west and moves upstream off Les Escoumins, while the other moves seaward along the north shore. At the estuary-gulf boundary near Pointe-des-Monts, the influence of the cyclonic Anticosti gyre and the topography of the shoreline deflect this current towards the south coast where it mixes with the Gaspé Current (Neu 1970, El-Sabh 1979). This surface circulation pattern gives rise to 2 eddies: a large anticyclonic one centered between the mouth of the Estuary and Baie-Comeau, and a smaller cyclonic eddy between Rimouski and mouth of the Saguenay cross sections (El-Sabh et al. 1982, Mertz et al. 1989) (Fig. 1B). Another striking feature is the upwelling of cold waters from the deeper intermediate layer at the head of the Laurentian Channel. These waters have a strong impact both on the surface characteristics of this region and on the Gaspé Current transport (Ingram 1979, Bugden 1981).

In the Gulf the general surface circulation is counterclockwise, with a 2-way flow in Cabot and Belle-Isle Straits (El-Sabh 1977a, Petrie et al. 1988). Several gyres, 20 to $100 \mathrm{~km}$ in diameter, occur in this area but their location and persistence vary appreciably, except for the Anticosti gyre which persists at all times. This cyclonic gyre, together with the density front formed at the entrance of the Gulf and the Gaspé Current, are the main features of the surface circulation in the western portion of the Gulf. The Gaspé Current remains a striking feature until it enters the open Gulf. It then spreads out in a general southeasterly direction and becomes weaker over the Magdalen Shallows. Part of this water is recirculated around the Gulf and part exits to the Atlantic Ocean through Cabot Strait (El-Sabh 1976, Dickie \& Trites 1983) (Fig. 1C). The northern portion of the Gulf receives considerable freshwater input from surrounding rivers and experiences episodic upwellings of cold waters, presumably induced by winds and tidal mixing (Lauzier et al. 1957, Steven 1974, Lacroix et al. 1985)

\section{MATERIALS AND METHODS}

Sampling of fauna. Navigation buoys, moored by Transport Canada from May through November of each year along shores of the Estuary and northwestern Gulf of St. Lawrence (Fig. 2), were used as collectors. The Estuary includes here the Lower and Upper Estuary as well as the lower hundred kilometres of the Fluvial Estuary. Sampling was carried out from 1974 to 1985 (except in 1978 and 1979), on up to 239 collectors per year. During winter the buoys were scraped and painted. The paint used contained no antifouling agents and, as a result, the buoys moored each spring had clean surfaces offering apparently little or no resistance to larval settlement. Throughout the annual 7 mo immersion period, the buoys were colonized by sessile organisms, presumably according to the relative abundance of their planktonic larvae. Since the buoys were moored and retrieved each year over short periods of time (about $2 \mathrm{wk}$ ), little or no seasonal differences in abundance among regions were introduced. The attached invertebrate fauna was sampled following the methods described in Fradette \& Bourget (1980, 1981), Ardisson et al. (1990), and Ardisson \& Bourget (1991). First, all macroscopic species observed on the buoys were collected and identified. Second, the species composition on each buoy was corroborated by examining a $0.01 \mathrm{~m}^{2}$ quantitative sample obtained from the area of maximum abundance of each one of the following dominant species: the hydroid Obelia longissima; the bivalves Hiatella arctica and Mytilus edulis; and the cirripedes Semibalanus balanoides, and Balanus crenatus. The areas of maximum abundance were determined by visual inspection. Since the species distributions on the buoys were most often patchy, sampling the community in the areas of maximum abundance was the most practical way to obtain comparable data among buoys. The only alternative would have been to randomly select a large number of quadrats on each buoy, which would have generated an unmanageable number of samples

Data analysis and underlying ecological models. The yearly presence-absence species data were used to identify the invertebrate associations in the area under study. Each year's binary data wrere assembled 


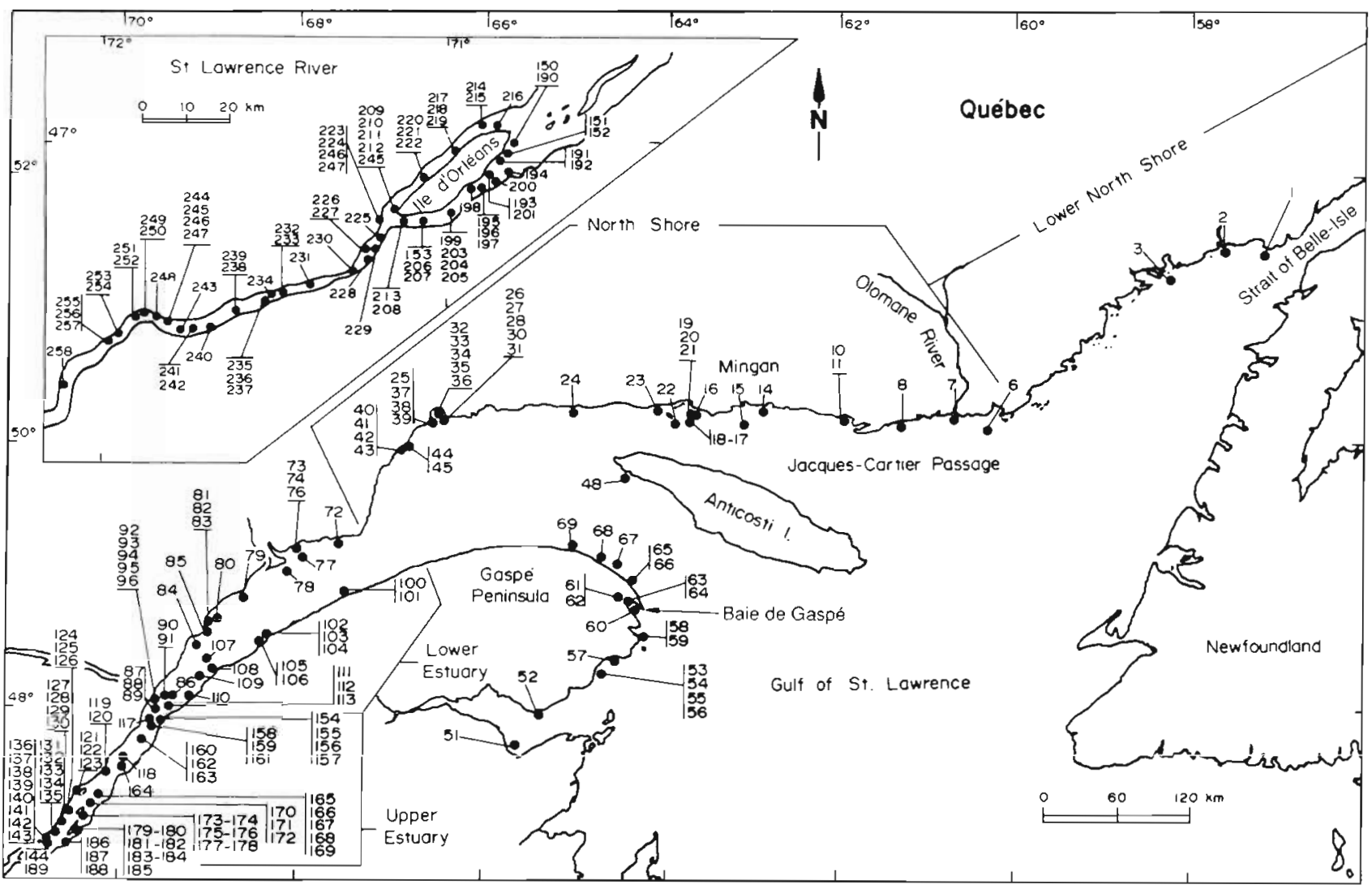

Fig. 2. Position of the sampling stations in the Estuary and northwestern Gulf of St. Lawrence

into a matrix of species $x$ stations. The Fager \& McGowan (1963) coefficient of association $S_{\mathrm{ab}}\left(S_{24}\right.$ in Legendre \& Legendre 1984) was then used to compute pairwise similarities among all species. This coefficient consists of the geometric mean of the proportion of joint occurrences, corrected for sample size:

$$
S_{a b}=\left[J_{a b} /\left(N_{a} N_{i b}\right)^{1 / 2}\right]-\left[1 / 2\left(N_{b}\right)^{1 / 2}\right]
$$

where $J_{a b}$ is the number of joint occurrences, $N_{a}$ and $N_{b}$ are the total number of occurrences of species ' $a$ ' and 'b', and $N_{b} \geq N_{\mathrm{a}}$. Pairs of species for which $S_{a b}$ was greater than 0.50 were considered to show positive affinity for each other. The unweighted pair group method of cluster analysis using arithmetic averages (UPGMA; Rohlf 1963) was used to form groups within which all species pairs showed positive affinity. UPGMA was preferred to other agglomerative hierarchical methods because it gave the highest correlation between the original similarities and the cophenetic matrix (similarities implied by the dendrogram). Only the independent groups of at least 3 related species were considered as associations of species (Krylov 1968). In accordance with Venrick (1971), the species not clustered but showing affinities with other species within one or more groups were considered satellites of those groups. In order to reduce the error of perspective imposed by the spatial scale used in determining the invertebrate associations of species, 5 different geographic scales, from coarse to fine, were examined: the whole system (Estuary and Gulf), the Estuary and the Gulf regions taken separately, the Gaspé Peninsula area, and the North Shore/Lower North Shore area.

The presence-absence data were then used to show the overall heterogeneity in species distribution at the Estuary-Gulf system scale. Here, the yearly binary data were assembled into 3 data matrices of species $\times$ stations. Stations in the matrices were ordered to form 3 one-dimensional spatial series of contiguous collectors, parallel to the coast, representing 3 very schematic potential pathways for dispersing species (Fig 3). The first pathway (Model 1) corresponds to a dispersal route following the counter-clockwise surface water circulation bordering the Lower North Shore, the North Shore and the Gaspé Peninsula. The second pathway (Model 2) corresponds to a dispersal route following the same circulation pattern along the Lower North Shore and the North Shore, and then the possible penetration of part of this water mass into the 
intermediate layer flowing along the north coast of the Estuary. Finally, the third pathway (Model 3) corresponds to a route following the surface water outflow along the River, the south coast of the Estuary, and the Gaspé Peninsula. These potential pathways of dispersal for marine and freshwater species are based on the general circulation patterns of the surface and intermediate water layers of the Estuary-Gulf system (see section 'Study area' above). Since the sampling stations were spatially ordered along virtual lines (Fig. 2), the sequences of buoys along a series were of interest at large and intermediate spatial scales but irrelevant at a scale of tens of kilometres.

The spatial discontinuities in species distribution were determined by analyzing the 'optimal' locations where limits may be placed separating groups of contiguous stations along these virtual lines, in accordance with the method of Godron (1966). Thus, on a line composed of $N$ stations and $P$ presences of a species $E$, the number of combinations $C$ of the $N$ stations taken $P$ at a time, assuming that each combination is equally probable, is computed as:

$$
C_{N}^{P}=\frac{N !}{P !(N-P) !}
$$

The uncertainty represented by the number of combinations gives a direct measure of the heterogeneity of the line with respect to the species $E$. Therefore, the amount of information $H_{t}$ (measured in binons or bits), corresponding to knowing the exact position of each of the stations where the species occurs, is:

$$
H_{\mathrm{t}}=\log _{2} C_{N}^{P}
$$

Heterogeneity is nil when $P=0$ or $N$, and maximum when $P=N / 2$. From this, the limit value $V$ for a particular station $L$ situated on a line is given by:

$$
V(L)=H_{\mathrm{t}}-\left(H_{\mathrm{g}}+H_{\mathrm{d}}\right)
$$

Here, $H_{\mathrm{g}}$ and $H_{\mathrm{d}}$ represent, respectively, the residual heterogeneity for the line fraction on the left and the right sides of the limit. After testing in this way for the limits of all the stations of the line, the average information for all species contained in the matrix was computed as $V \mathrm{~m}$. The unbiased limit values of $V m$ (termed here $V r$ ) were obtained by dividing each value of $V m$ by its individual mathematic expectancy (Ve). The sites of higher $V r$ values corresponded to the sites of higher overall heterogeneity and, consequently, to the 'optimal' limits between groups of stations along the considered line (Godron \& Bacou 1975, Gauthier \& Godron 1976).

Then we searched for the species whose first and last presence on the lines were statistically significant. According to Forman \& Godron (1986), the information

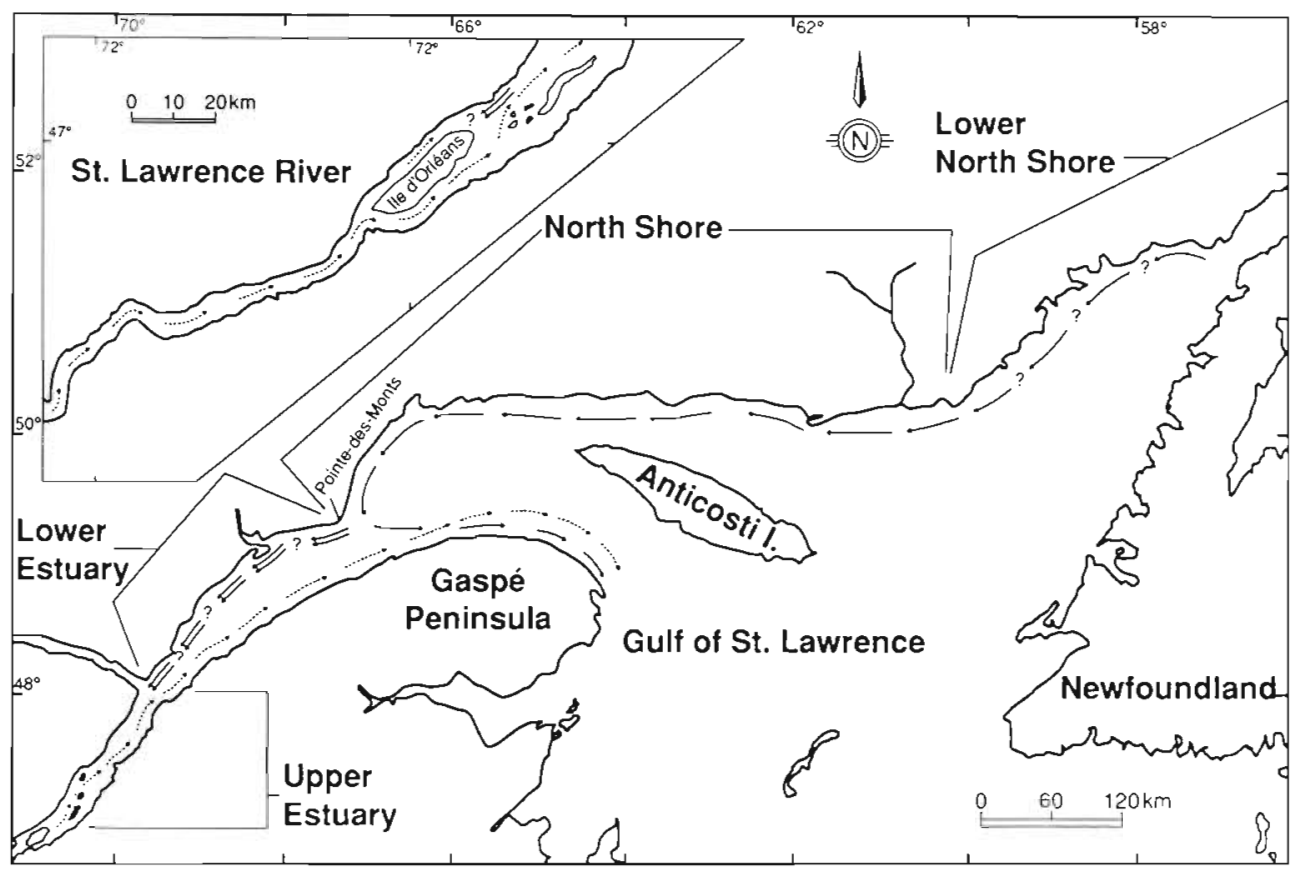

Fig. 3. Potential pathways for larval dispersal of marine and freshwater species, based on the general circulation patterns of the surface and intermediate water layers of the Estuary and northwestern Gulf of St. Lawrence. Model 1: continuous arrows; Model 2: continuous arrows up to Point-des-Monts plus double arrows up to the head of the Lower Estuary; Model 3: dotted arrows 
$I_{\mathrm{d}}$ gained when observing a species first appearing in the Dth station along a line (the beginning) is obtained by computing:

$$
I_{\mathrm{d}}=H_{\mathrm{l}}-\log _{2} \frac{(N-D) !}{(P-1) !(N-D-P+1) !}
$$

In the same way, the information $I_{f}$ gained when observing that the end of a species is in station F along the line is:

$$
I_{\mathrm{I}}=H_{\mathrm{t}}-\log _{2} \frac{(F-1) !}{(P-1) !(F-P) !}
$$

These calculations, computed for each of the species, allowed us to identify the species contributing most to the discontinuities observed on each line.

\section{RESULTS}

\section{Frequency and species composition by subregion}

Sampling of epibenthos on buoys yielded 68 invertebrate species (Table 1). Among these, there worc 42 motile species from the taxa Gastropoda (10 species), Polychaeta (10), Isopoda (2), Amphipoda (12), Echinodermata (3), Pycnogonida (1), Decapoda (2) and Insecta (2), as well as 26 sessile species from the taxa Bryozoa (1), Hydroida (15), Bivalvia (5), and Cirripedia (5). Not all these species were continuously observed during the entire period of study. The number of species over all buoys fluctuated between 20 and 40 from year to year, with an average value of 31 species per year.

Among the species observed, only $13(19 \%, 6$ motile and 7 sessile) were always present and more than half $(57 \%)$ were occasional or infrequent (present during 3 yr or less over a sampling period of $10 \mathrm{yr}$ ). Results given in Table 2 show that the more frequent a species was, the larger its geographic range of distribution.

Of the total number of species, $91 \%$ were present in the Gulf whereas only $57 \%$ were observed in the Estuary. At a smaller spatial scale, the largest number of species (51/68) was observed along the North Shore (Anticosti Island included), then along the Gaspé Peninsula $(47 / 68)$. It should be stressed that the species observed in Anticosti Island waters (17/68) were also observed in the North Shore area and, excluding Clytia hemisphaerica, in the Gaspé Peninsula area as well. The Lower North Shore included less than half the species observed on the North Shore (22/68). Similarly, the Upper Estuary had half the species $(16 / 68)$ observed in the Lower Estuary (32/68). Species richness on the north shore of the Estuary was about one third higher than that observed on the south shore. Finally, the number of species dropped to $6 / 68$ in the
Fluvial Estuary. The ranking of regions changed, however, when the average of the number of species present per buoy and region were estimated. From 2 to 13 species per buoy were observed in the Gulf, and from 0 to 10 in the Estuary. The largest average values were observed on the Gaspé Peninsula (8.0), the North Shore (7.2), Anticosti Island (7.0) and the Lower North Shore (6.9). The values dropped to 2.9 in the Lower Estuary, 0.9 in the Upper Estuary, and 0.2 in the River (Table 3).

The motile fauna represented $62 \%$ of the total number of epibenthic species on the buoys. The number of species in the Gulf (38) was higher than that observed in the Estuary (23). Species richness by subregion closely followed the pattern outlined above for the total fauna. Three groups of organisms - Gastropoda, Polychaeta and Amphipoda - dominated the motile fauna (frequency between 79 and $95 \%$, depending on years). The gastropod Lacuna vincta, the polychaetes Lepidonotus squamatus, Nereis pelagica and Phyllodoce maculata, and the amphipods Calliopius laeviusculus, Caprella septentrionalis, Ischyrocerus anguipos and Pontogoncia incrmis woro the most frequent species both in the Gulf and in the Estuary. On the other hand, the gastropod Acmaea testudinalis, the amphipods Gammarus oceanicus, Gammarus tigrinus and $I$. anguipes, and the larvae of the insects Ephemerella sp. and Hydropsyche recurvata were the only species observed in the Fluvial Estuary. Whereas Ephemerella sp. was confined to the River, H. recurvata was observed in the Upper Estuary as well. No more than $20 \%$ of the buoys moored in the River $(n=75)$ were colonized by motile fauna each year.

As for the motile fauna, the largest number of sessile species was observed in the Gulf (24), then in the Estuary (16). From these, the North Shore (Anticosti Island included) held the largest number of species (20), followed by the Gaspé Peninsula (18). Numbers dropped to 14 species in the Lower Estuary, and 11 species in the Lower North Shore region. Only 8 species were observed in the Upper Estuary and none in the River.

\section{Limits of distribution of the recurrent sessile fauna}

The recurrent sessile fauna (the sessile fauna present on buoys during the entire period of study) was largely distributed in the Gulf and to a lesser degree in the Estuary. However, distribution ranges differed among species (Fig 4). Mytilus edulis and Balanus crenatus were observed on all buoys moored in the Gulf and on about one third of those moored in the Upper and Lower Estuary. The frequency of observation of Semibalanus balanoides, Obelia longissima and Hiatella arctica on buoys ranged between 90 and $97 \%$ for the 
Table 1 Species composition of the Estuary and Gulf of St. Lawrence epibenthic fauna observed on the buoys during the period 1974 to 1985

\section{Motile species}

Mollusca: Gastropoda

Acmaea testudinalis (O. F. Müller, 1776)

Dendronotus frondosus (Ascanius, 1774)

Doto coronata (Gmelin, 1791)

Lacuna pallidula neritoidea Gould, 1840

Lacuna vincta (Montagu, 1803)

Littorina littorea (Linnaeus, 1758)

Littorina obtusata (Linnaeus, 1758)

Margarites helicinus (Phipps, 1774)

Mitrella rosacea (Gould, 1841)

Nudibranchiata ${ }^{a}$

Annelida: Polychaeta

Autolytus cornutus Agassiz, 1863

Harmothoe extenuata (Grube, 1840)

Harmothoe imbricata (Linnaeus, 1767)

Lepidonotus squamatus (Linnaeus, 1766)

Nereis pelagica (Linnaeus, 1758)

Paranaites speciosa (Webster, 1880)

Pholoe sp.

Phyllodoce maculata (Linnaeus, 1767)

Spirorbis sp.

Terebellidae ${ }^{a}$

Crustacea: Isopoda

Idothea phosphorea (Harger, 1873)

Jaera marina (Fabricius, 1780)

Crustacea: Amphipoda

Aeginina longicornis (Kröyer, 1842)

Calliopius laeviusculus (Kröyer, 1838)

Caprella linearis (Linnaeus, 1758)

Caprella septentrionalis Kröyer, 1838

Gammarellus angulosus (Rathke, 1843)

Gammarellus homari (J. C. Fabricius, 1779)

Gammarus oceanicus Segestrale, 1947

Gammarus tigrinus Sexton, 1939

Ischyrocerus anguipes Kröyer, 1838

Jassa falcata (Montagu, 1808)

Metopa sp.

Pontogeneia inermis (Kröyer, 1838)

Echinodermata

Asterias vulgaris Verril, 1866

Ophiura robusta (Ayres, 1851)

Strongylocentrotus droebachiensis (O. F. Müller, 1776)
Pycnogonida

Phoxichilidium femoratum (Rathke)

Crustacea: Decapoda

Cancer irroratus (Say, 1817)

Hyas sp.

Insecta

Ephemerella sp

Hydropsyche recurvata (Banks, 1914)

\section{Sessile species}

Bryozoa $^{a}$

Hydroida

Abietinaria abietina (Linnaeus, 1758)

Bougainvillia sp.

Callycella syringa (Linnaeus, 1767)

Campanularia integra (Macgillivray, 1842)

Clytia hemisphaerica (Linnaeus, 1767)

Eulaomeda sp.

Halecium sp.

Hydrallmania falcata (Linnaeus, 1758)

Obelia dichotoma (Linnaeus, 1758)

Obelia geniculata (Linnaeus, 1758)

Obelia longissima (Pallas, 1766)

Opercularella lacerata (Johnston, 1847)

Rhizocaulus verticillatus (Linnaeus, 1758)

Sertularia cupressina (Linnaeus, 1758)

Tubularia larynx (Ellis \& Solander, 1786)

Mollusca: Bivalvia

Anomia aculeata (O. F. Müller, 1776)

Hiatella arctica (Linnaeus, 1767)

Mesodesma arctatum (Conrad, 1831)

Mya arenaria Linnaeus, 1758

Mytilus edulis Linnaeus, 1758

Crustacea: Cirripedia

Semibalanus balanoides (Linnaeus, 1766)

Balanus balanus (Linnaeus, 1758)

Balanus crenatus (Bruguière, 1789)

Balanus improvisus (Darwin, 1854)

Lepas anatifera (Linnaeus, 1758)

${ }^{a}$ One species only
Gulf and between 8 and $27 \%$ for the Estuary. On the other hand, Tubularia larynx and Obelia geniculata were observed on about $50 \%$ of the buoys in the Gulf and $<6 \%$ of the buoys in the Estuary.

The northeastern distribution for all the species except Tubularia larynx extended up to the limit of the sampling area in the Strait of Belle-Isle (Figs. 2 \& 4). While all species were well distributed in the Gaspé Peninsula waters, their inner limit within the Estuary varied depending on species. Mytilus edulis exhibited the largest distribution range. It extended upstream as far as the eastern tip of l̂le d'Orléans $\left(47^{\circ} 01^{\prime} \mathrm{N}\right.$, $\left.70^{\circ} 46^{\prime} \mathrm{W}\right)$. In decreasing order, Hiatella arctica and Obelia longissima were, respectively, observed in the neighbouring areas of Sault-au-Cochon $\left(47^{\circ} 12^{\prime} \mathrm{N}\right.$, $\left.70^{\circ} 36^{\prime} \mathrm{W}\right)$ and Cap Maillard $\left(47^{\circ} 16^{\prime} \mathrm{N}, 70^{\circ} 35^{\prime} \mathrm{W}\right)$ on the north shore of the Upper Estuary. Balanus crenatus was well represented in the area surrounding île aux Coudres. Their inner position in the Estuary was $49^{\circ} 20^{\prime} \mathrm{N}, 70^{\circ} 17^{\prime} \mathrm{W}$. The linit of Obelia geniculata in the Estuary was the mouth of the Saguenay Fjord $\left(48^{\circ} 08^{\prime} \mathrm{N}\right.$, $69^{\circ} 36^{\prime}$ W). Downstream, Semibalanus balanoides was 
Table 2. Distribution of the Estuary and Gulf of St. Lawrence epibenthic fauna observed on buoys during the period 1975 to 1985. Species are ordered by class of frequency. WNS: Western North Shore; MR: Mingan region; ENS: Eastern North Shore; I. "JS: Lower North Shore; AI: Anticosti Island; NGP: Northern Gaspé Peninsula; SGP: Southern Gaspé Peninsula; -_- range of distribution of species

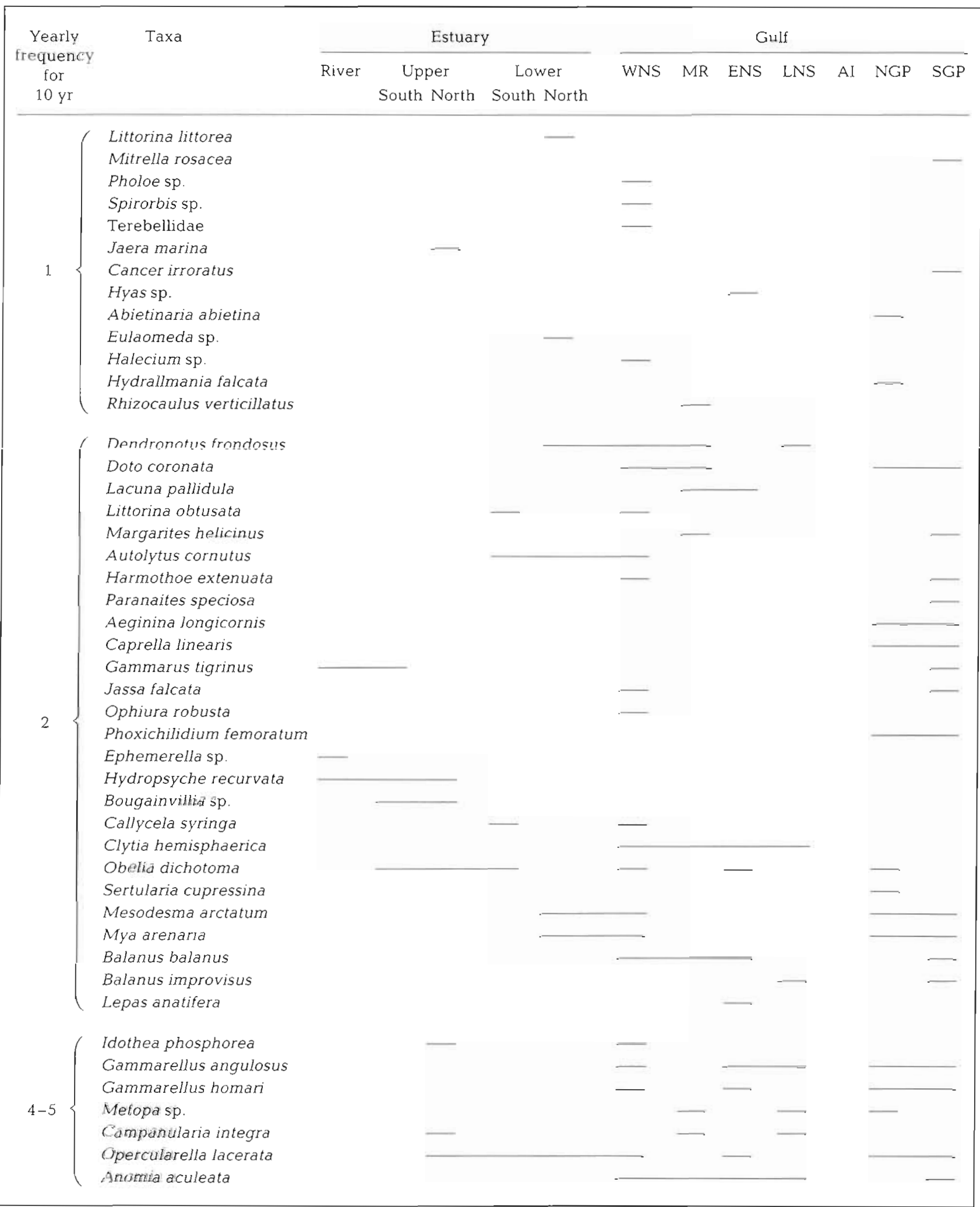


Table 2 (continued)

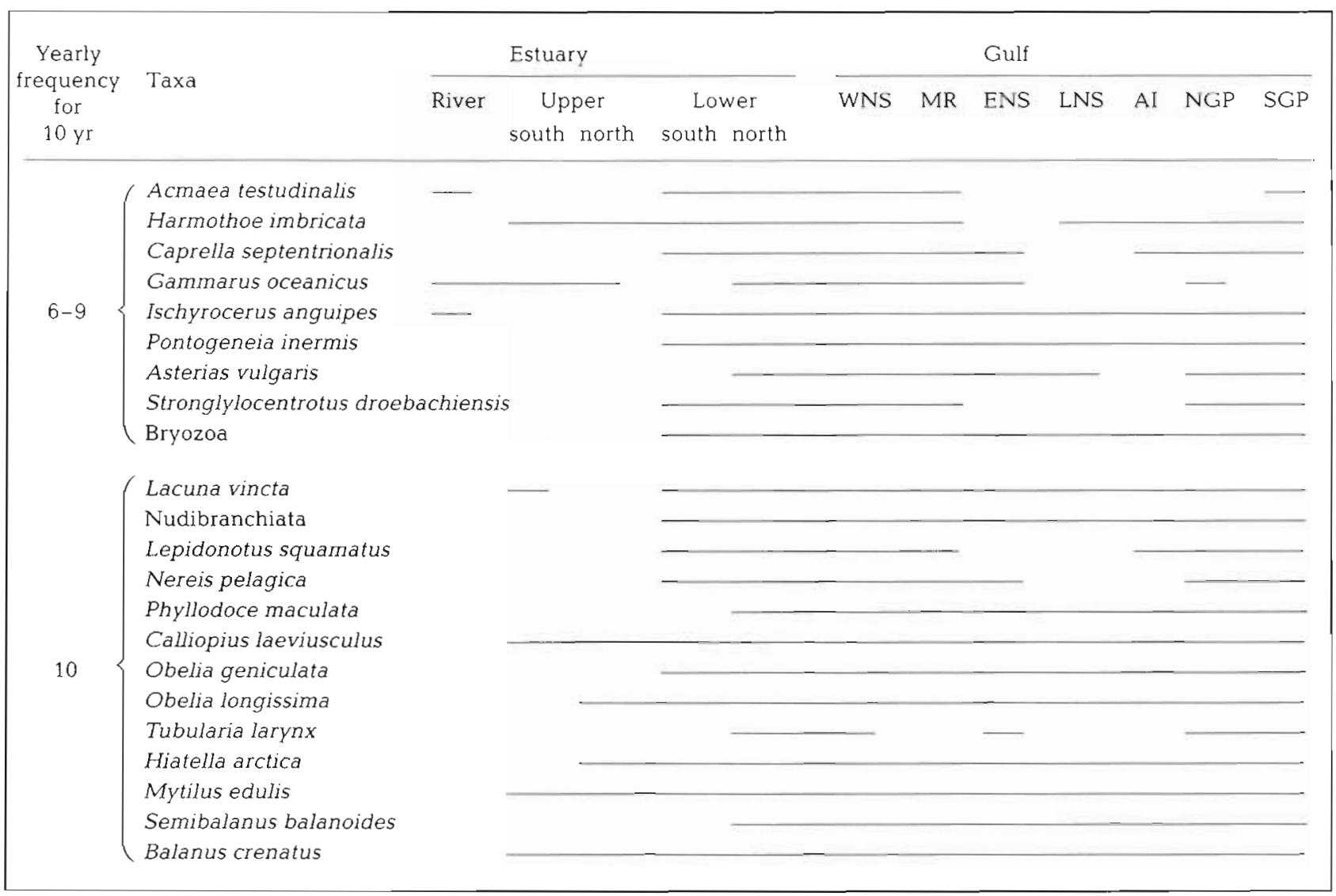

Table 3. Species richness of the Estuary and Gulf of St. Lawrence epibenthic fauna observed on buoys during the period 1974 to 1985. Numbers in normal print represent numbers of species present in a given region. Boldface numbers indicate total numbers of different species present in the region indicated by a given bracket

\begin{tabular}{|c|c|c|c|c|c|c|c|c|c|}
\hline \multirow[t]{3}{*}{ Species } & \multirow{3}{*}{ River } & \multicolumn{4}{|c|}{ Estuary } & \multicolumn{4}{|c|}{ Gulf } \\
\hline & & \multicolumn{2}{|c|}{ Upper } & \multicolumn{2}{|c|}{ Lower } & \multirow[t]{2}{*}{ Gaspé Pen } & \multirow[t]{2}{*}{ Anticosti Is. } & \multirow[t]{2}{*}{ North Shore } & \multirow[t]{2}{*}{ Lower North Shore } \\
\hline & & South & North & South & North & & & & \\
\hline \multirow[t]{3}{*}{ Motile } & 6 & 6 & 6 & 13 & 17 & 29 & 9 & 31 & 11 \\
\hline & & \multicolumn{2}{|c|}{8} & \multicolumn{2}{|c|}{18} & \multicolumn{4}{|c|}{31} \\
\hline & \multicolumn{5}{|c|}{23} & \multicolumn{4}{|c|}{38} \\
\hline \multirow[t]{3}{*}{ Sessile } & 0 & 4 & 8 & 9 & 12 & 18 & 8 & 20 & 11 \\
\hline & & \multicolumn{2}{|c|}{8} & \multicolumn{2}{|c|}{14} & \multicolumn{4}{|c|}{20} \\
\hline & \multicolumn{5}{|c|}{16} & \multicolumn{4}{|c|}{24} \\
\hline \multirow[t]{3}{*}{ Total } & 6 & 10 & 14 & 22 & 29 & 47 & 17 & 51 & 22 \\
\hline & 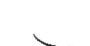 & \multicolumn{2}{|c|}{$\sqrt{16}$} & \multicolumn{2}{|c|}{$\sqrt{32}$} & \multicolumn{4}{|c|}{51} \\
\hline & \multicolumn{5}{|c|}{39} & \multicolumn{4}{|c|}{62} \\
\hline $\begin{array}{l}\text { Average no. } \\
\text { of species per } \\
\text { buoy and regio }\end{array}$ & $\begin{array}{l}0.2 \\
\text { on }\end{array}$ & 1.0 & 0.9 & 2.8 & 3.0 & 8.0 & 7.0 & 7.2 & 6.9 \\
\hline
\end{tabular}



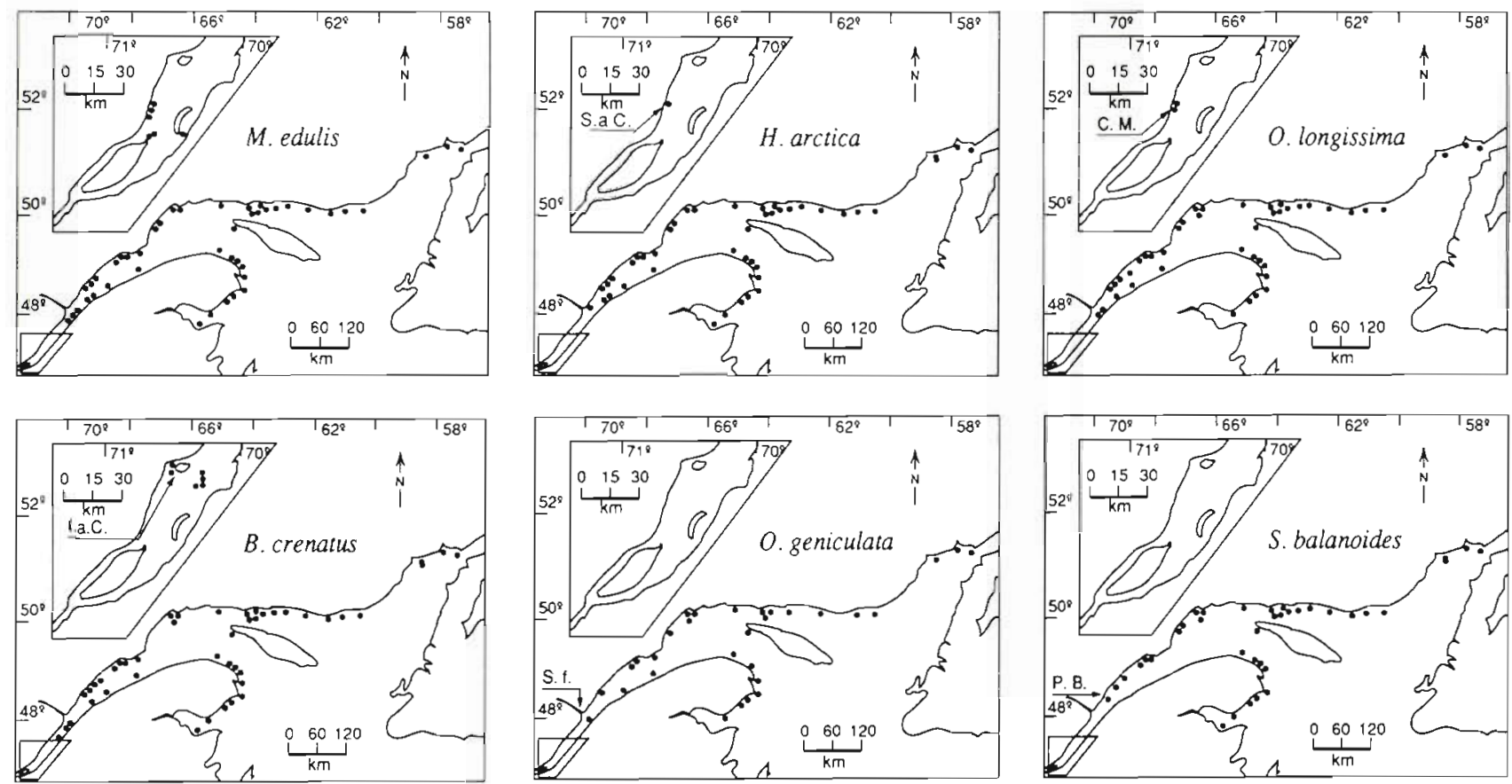

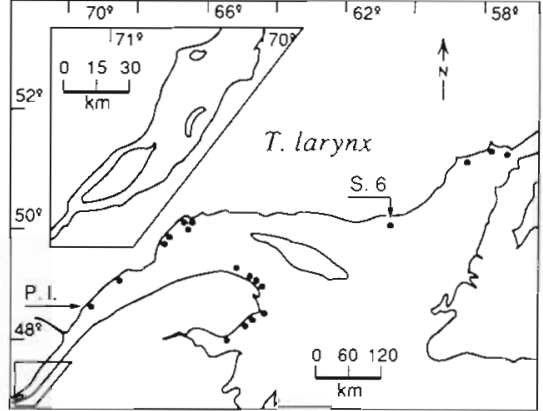

Fig. 4. Distribution of the recurrent sessile species in the Estuary and northwestern Gulf of St. Lawrence during the period 1974 to 1985. • Localities (groups of buoys) where the species were observed every year; S.a.C.: Sault-au-Cochon; C.M.: Cap Maillard; I.a.C.: Ille aux Coudres; S.f.: Saquenay fjord; P.B.. Pointe-au-Boisvert; P.I.: Portneuf locality; S.6: Station 6. For full genus names see Table 1 observed near Pointe-au-Boisvert, south of Portneuf (48 $\left.33^{\prime} \mathrm{N}, 69^{\circ} 07^{\prime} \mathrm{W}\right)$. T. larynx had the narrowest distributional range of all these species; it extended from Station $6\left(50^{\circ} 07^{\prime} \mathrm{N}, 60^{\circ} 19^{\prime} \mathrm{W}\right)$, on the North Shore, to Portneuf $\left(48^{\circ} 44^{\prime} \mathrm{N}, 68^{\circ} 58^{\prime} \mathrm{W}\right)$ in the Lower Estuary.

\section{Species associations}

At the whole system spatial scale, the major group of co-occurring species was composed of 17 species, among which 12 were grouped at $S>0.50$ and 5 others were satellite species linked at lower similarity levels (Table 4). Obelia longissima, Mytilus edulis, Balanus crenatus, Hiatella arctica, Semibalanus balanoides, Ischyrocerus anguipes and Lacuna vincta frequently grouped together, whereas Lepidonotus squamatus, Nereis pelagica, Calliopius laeviusculus, Phyllodoce maculata and the nudibranch species either were not present or were satellite species during at least half of the $10 \mathrm{yr}$ period. Although individual species were not always present from year to year, the same basic species group persisted in time. Analyses carried out at the intermediate geographic scale (region) yielded about the same basic group, although some changes in species composition were observed (Table 5). At this spatial scale, the number of species tended to decrease due to reduced affinities of particular species with the other members of the group. For instance, $S$. balanoides became a satellite species only when it was viewed at the Gaspé Peninsula scale. Also, these analyses showed individual species joining the epibenthic association. only in some particular regions of the study area, e.g. Harmothoe imbricata in the North Shore/Lower North Shore area, or Acmaea testudinalis, Eulaomedasp., and Autolytus cornutus in the Estuary area (Table 5). A secondary group (association), observed only in 1981 at the large spatial scale (Table 4), was formed by Obelia geniculata. Anomia aculeata and S. balanoides, with Tubularia larynx as satellite species. Along the temporal axis, the yearly variation in species composition of the main epibenthic group at all but the Estuary scale, 
Table 4. Yearly species composition of the main epibenthic group formed at $S>0.50$ (Fager and McGowan's index of association), viewed at large (Estuary and Gulf) geographic scale. (+) Present; (-) not observed; (s) satellite species (linked at similarity levels $\leq 0.50) ;(\&)$ secondary group (members of the second association)

\begin{tabular}{|c|c|c|c|c|c|c|c|c|c|c|}
\hline \multirow[t]{2}{*}{ Species } & \multicolumn{10}{|c|}{ Year } \\
\hline & 1974 & 1975 & 1976 & 1977 & 1980 & 1981 & 1982 & 1983 & 1984 & 1985 \\
\hline Obelia longissima & + & + & + & + & + & + & + & + & + & + \\
\hline Mytilus edulis & + & + & + & + & + & + & + & + & + & + \\
\hline Balanus crenatus & + & + & + & + & + & + & + & + & + & + \\
\hline Hiatella arctica & + & + & + & + & + & + & + & + & + & + \\
\hline Semibalanus balanoides & + & + & + & + & + & $\&$ & + & + & - & + \\
\hline Ischyrocerus anguipes & - & + & $\mathrm{s}$ & - & + & + & + & + & + & + \\
\hline Lacuna vincta & s & - & + & + & + & + & + & + & + & + \\
\hline Nudibranchiata & - & - & $s$ & s & + & + & + & + & s & $s$ \\
\hline Lepidonotus squamatus & s & - & s & s & + & - & - & $\mathrm{s}$ & + & s \\
\hline Nereis pelagica & - & s & s & s & - & - & + & + & - & s \\
\hline Calliopius laeviusculus & s & s & s & - & s & s & + & + & s & + \\
\hline Phyllodoce maculata & - & - & - & s & - & - & s & s & - & + \\
\hline Caprella septentrionalis & - & - & - & - & - & - & - & $\mathrm{s}$ & - & $\mathrm{s}$ \\
\hline Dendronotus frondosus & - & $\mathrm{s}$ & - & - & - & - & - & - & - & - \\
\hline Tubularia larynx & - & - & - & $\mathrm{s}$ & - & $\&$ & $s$ & $s$ & $\mathrm{~s}$ & - \\
\hline Harmothoe imbricata & - & - & - & - & - & - & $\mathrm{s}$ & - & - & $\mathrm{s}$ \\
\hline Obelia geniculata & - & - & - & - & - & $\&$ & - & s & - & - \\
\hline
\end{tabular}

Table 5. Changes in species composition of the main epibenthic group formed at $S>0.50$ (Fager and McGowan's index of association) during the period 1974 to 1985 , when viewed at different geographic scales. (+) Present; (-) not observed; (s) satellite species (linked at similarity levels $\leq 0.50$ )

\begin{tabular}{|c|c|c|c|c|c|}
\hline \multirow[t]{2}{*}{ Species } & \multicolumn{5}{|c|}{ Geographic scale } \\
\hline & $\begin{array}{c}\text { Estuary and } \\
\text { Gulf }\end{array}$ & Gulf & Estuary & $\begin{array}{c}\text { Gaspé } \\
\text { Peninsula }\end{array}$ & $\begin{array}{c}\text { North Shore/ } \\
\text { Lower North Shore }\end{array}$ \\
\hline Obelia longissima & + & + & + & + & + \\
\hline Mytilus edulis & + & + & + & + & + \\
\hline Balanus crenatus & + & + & + & + & + \\
\hline Hiatella arctica & + & + & + & + & + \\
\hline Semibalanus balanoides & + & + & + & $\mathrm{s}$ & + \\
\hline Ischyrocerus anguipes & + & + & + & + & + \\
\hline Lacuna vincta & + & + & s & + & + \\
\hline Nudibranchiata & + & + & + & s & + \\
\hline Lepidonotus squamatus & + & + & - & + & + \\
\hline Nereis pelagica & + & + & s & + & + \\
\hline Calliopius laeviusculus & + & + & $\mathrm{s}$ & + & + \\
\hline Phyllodoce maculata & + & + & s & + & s \\
\hline Asterias vulgaris & - & - & - & + & - \\
\hline Harmothoe imbricata & - & - & - & - & + \\
\hline Caprella septentrionalis & s & s & - & s & s \\
\hline Dendronotus frondosus & s & s & - & - & - \\
\hline Tubularia larynx & s & s & - & s & s \\
\hline Obelia geniculata & $\mathrm{s}$ & s & - & $\mathrm{s}$ & $\mathrm{s}$ \\
\hline Anomia aculeata & - & $\mathrm{s}$ & - & - & $\mathrm{s}$ \\
\hline Acmaea testudinalis & - & - & s & - & - \\
\hline Eulaomeda sp. & - & - & s & - & - \\
\hline Autolytus cornutus & - & - & s & - & - \\
\hline Doto coronata & - & - & - & s & - \\
\hline Bryozoa & - & - & - & s & - \\
\hline Caprella linearis & - & - & - & s & - \\
\hline Gammarellus homari & - & - & - & $\mathrm{s}$ & - \\
\hline Gammarellus angulosus & - & - & - & - & s \\
\hline Mya arenaria & - & - & - & - & s \\
\hline Obelia dichotoma & - & - & - & - & s \\
\hline
\end{tabular}


followed closely the picture shown in Table 4 . In the Estuary area (not shown), the number of species taking part in the species association for particular years was very low and no association between them was observed in 1977, 1981, and 1983.

\section{Spatial heterogeneity in species distribution}

During the period 1974 to 1985 , the major breakpoints $(V r)$ along a given line (Models 1 to 3 ) did not always occur at the same locations. Further, the relative importance of these discontinuities was highly variable across years (Fig. 5). For instance, in 1977 (Fig. 5, Model 1) the most heterogeneous site corresponded to Station 42 (1.6 binons) whereas in 1983 (same model) the most heterogeneous one corresponded to Station 69 (2.2 binons). Indeed, the precise heterogeneity between each pair of stations depended on the heterogeneity of the entire line, the latter being in turn a function of the number of stations and species considered each year.

These discontinuities occurred at locations where several species appeared and disappeared abruptly each year (Table 6). Overall, results in Fig. 5 and Table

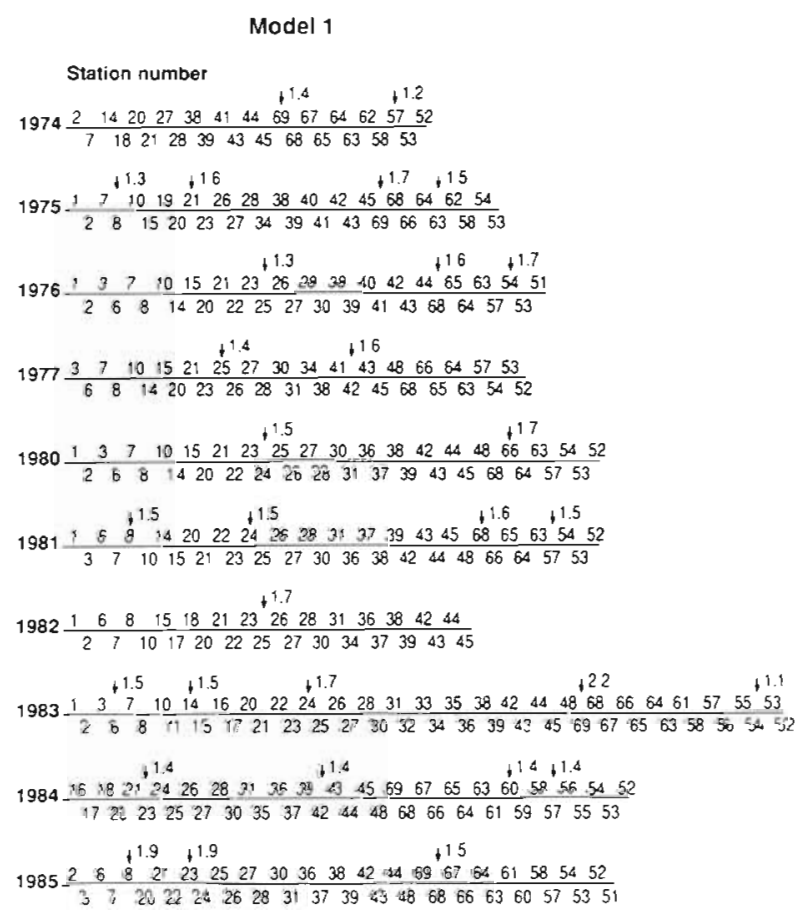

Model 3

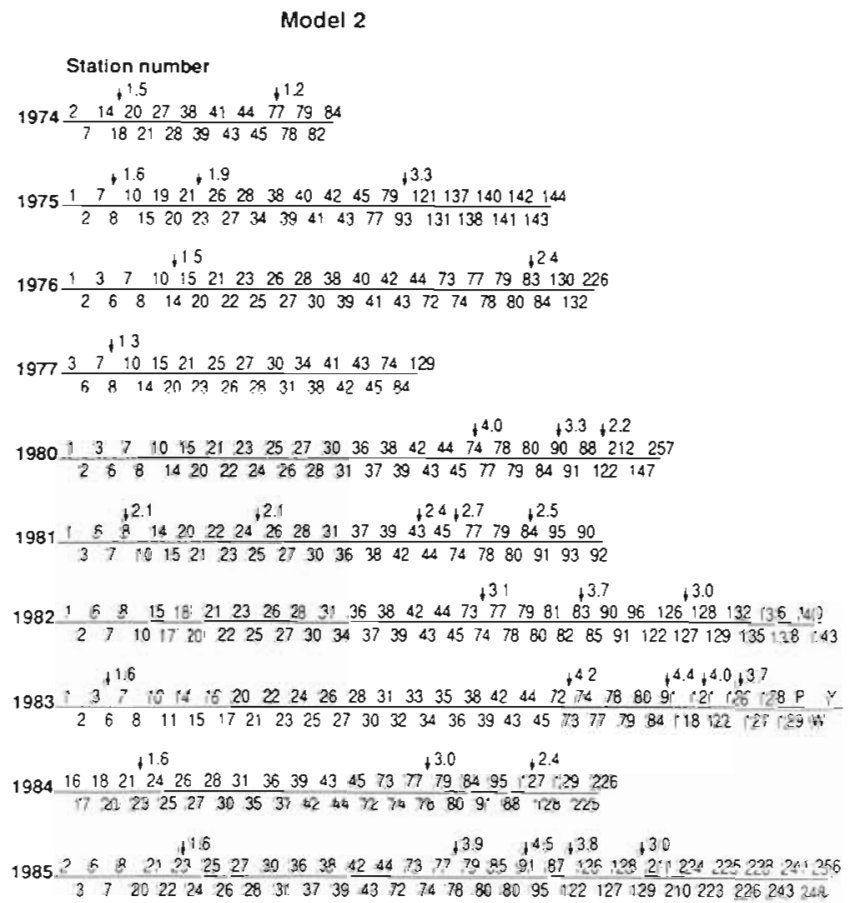

Fig. 5. Major yearly discontinuities along lines (models) 1, 2, and 3. Horizontal series of numbers represent contiguous stations (contiguous stations were arranged in top and bottom rows only to diminish the length of the lines); arrows point to stations where the optimal limits were found values associated with the vertical arrows indicate the amount of information (binons or bits) corresponding to each major discontinuity. Number of buoys sampled varied from year to year 
Table 6. Statistically significant cuts (beginnings and ends of species distributions) near areas of major heterogeneity. Significant beginnings and ends at a threshold of 0.05 (>4.3 binons) are indicated by left and right brackets, respectively. For full genus names see Table 1

\begin{tabular}{|c|c|c|}
\hline Station & Year & Species \\
\hline \multicolumn{3}{|c|}{ Model 1} \\
\hline 6 & 1983 & [L. anatifera], A. aculeata] \\
\hline 8 & $\begin{array}{l}1975 \\
1981 \\
1985\end{array}$ & $\begin{array}{l}\text { [1. anguipes } \\
\text { [Hyas sp.] } \\
\text { [Nudibranchiata, [S. balanoides, [L. vincta, [B. crenatus, [H. arctica }\end{array}$ \\
\hline 14 & 1983 & [N. pelagica \\
\hline 21 & 1975 & [N. pelagica, G. oceanicus] \\
\hline 23 & $\begin{array}{l}1984 \\
1985\end{array}$ & $\begin{array}{l}\text { [M. arenaria, [N. pelagica, [ T larynx } \\
{[\text { M. arctatum, [S. droebachiensis, [H. imbricata, }[\text { L. squamatus, }[N \text {. pelagica, }[T \text {. larynx, }} \\
\text { C. hemisphaerica] }\end{array}$ \\
\hline 24 & 1983 & [M. arenaria, [L. squamatus, [T. larynx \\
\hline 25 & $\begin{array}{l}1976 \\
1977 \\
1980 \\
1981 \\
1982\end{array}$ & $\begin{array}{l}\text { [L. squamatus } \\
\text { [Nudibranchiata } \\
\text { |P. maculata, [G. angulosus, [T. larynx, [L. squamatus } \\
\text { [N. pelagica, [L. squamatus, [T larynx } \\
\text { [A. cornutus, [C. syringa, [H. imbricata, [T larynx, [N. pelagica, [P. maculata }\end{array}$ \\
\hline 42 & $\begin{array}{l}1977 \\
1984\end{array}$ & $\begin{array}{l}\text { [S. droebachiensis], H. imbricata], Spirorbis sp.] } \\
\text { [Bryozoa], [S. droebachiensis, [O. lacerata, [G. angulosus, [P. maculata }\end{array}$ \\
\hline 68 & $\begin{array}{l}1976 \\
1981 \\
1985\end{array}$ & $\begin{array}{l}\text { C. laeviuculus] } \\
\text { [C. linearis], G. homari] } \\
\text { [A. longicornis, |A. vulgaris, O. lacerata], P. inermis] }\end{array}$ \\
\hline 69 & $\begin{array}{l}1974 \\
1975 \\
1983\end{array}$ & $\begin{array}{l}\text { [Nudibranchiata, [P. maculata, L. squamatus }] \\
{[G \text {. homari, }[\text { L. squamatus, C. septentrionalis }]} \\
\text { [C. linearis], [O. robusta], [S. cupressina }],[P \text {. femoratum], S. balanoides }]\end{array}$ \\
\hline 60 & 1984 & C. septentrionalis], G. oceanicus], $P$. inermis], A. vulgaris], M. arenaria] \\
\hline 63 & 1975 & [A. vulgaris, Bryozoa] \\
\hline 66 & 1980 & G. angulosus], Metopa sp.], P. inermis] \\
\hline 54 & $\begin{array}{l}1976 \\
1983\end{array}$ & $\begin{array}{l}\text { [H. extenuata } \\
\text { [S. droebachiensis], B. improvisus] }\end{array}$ \\
\hline 57 & $\begin{array}{l}1974 \\
1981 \\
1984\end{array}$ & $\begin{array}{l}\text { [J. falcata } \\
{[\text { H. imbricata], O. longissima] }} \\
{[\text { H. imbricata, C laeviusculus], O. lacerata] }}\end{array}$ \\
\hline \multicolumn{3}{|l|}{ Model 2} \\
\hline 6 & 1983 & [L. anatifera], A. aculeata] \\
\hline 8 & $\begin{array}{l}1975 \\
1981\end{array}$ & $\begin{array}{l}\text { [L. palidulla] } \\
{[\text { Hyas sp.] }}\end{array}$ \\
\hline 14 & 1976 & [D. coronata, $[$ H. imbricata \\
\hline 18 & 1974 & I. anguipes] \\
\hline 23 & $\begin{array}{l}1975 \\
1984 \\
1985\end{array}$ & $\begin{array}{l}\text { [M. helicinus], [N. pelagica } \\
\text { [P. inermis] } \\
{[\text { H. imbricata, [S. droebachiensis, [N. pelagica, [G. oceanicus, C. hemisphaerica] }}\end{array}$ \\
\hline 25 & 1981 & [N. pelagica, [L. squamatus, [T. larynx, P. maculata], C. septentrionalis], G. homari] \\
\hline 43 & 1981 & I. anguipes], Bryozoa], L. squamatus]], L. vincta], Nudibranchiata], A. aculeata], S. balanoides] \\
\hline 73 & 1983 & M. arenaria], L. vincta], O. geniculata] \\
\hline 74 & $\begin{array}{l}1980 \\
1981 \\
1982\end{array}$ & $\begin{array}{l}\text { [A. testudinalis, [Eulaomeda sp., J. falcata], T. lasynx], C. laviusculus], O. longissima], L. squamatus], } \\
\text { L. vincta], M. edulis] } \\
\text { C. laeviuculus], O. geniculata] } \\
\text { [S. droebachiensis], L. squamatus], H. imbricata], L. vincta], O. geniculata] }\end{array}$ \\
\hline
\end{tabular}


Table 6 (continued)

\begin{tabular}{|c|c|c|}
\hline Station & Year & Species \\
\hline 77 & 1974 & L. vincta], S. balanoides] \\
\hline 78 & $\begin{array}{l}1984 \\
1985\end{array}$ & $\begin{array}{l}\text { O. lacerata], } M \text {. arenaria], } H \text {. arctica] } \\
{[\text { A. cornutus], S. droebachiensis], L. vincta], Nudibranchiata], L. squamatus] }}\end{array}$ \\
\hline 83 & $\begin{array}{l}1976 \\
1982\end{array}$ & $\begin{array}{l}\text { H. arctica], S. balanoides], B. crenatus] } \\
P \text {. inermis], M. edulis], P. maculata], C. laeviusculus], Nudibranchiata], N. pelagica], I. anguipes] }\end{array}$ \\
\hline 84 & 1981 & H. arctica], B. crenatus] \\
\hline 90 & 1980 & Nudibranchiata], H. arctica] \\
\hline 91 & $\begin{array}{l}1983 \\
1985\end{array}$ & $\begin{array}{l}\text { Nudibranchiata], O. longissima], M. edulis] } \\
\text { O. geniculata], C. septentrionalis], P. maculata], I. anguipes], O. longissima], S. balanoides] }\end{array}$ \\
\hline 93 & 1975 & C. septentrionalis], I. anguipes], H. arctical \\
\hline 121 & 1983 & C. laeviusculus] \\
\hline 122 & $\begin{array}{l}1980 \\
1985\end{array}$ & $\begin{array}{l}\text { B. crenatus] } \\
\text { [C. integra], I. phosphorea], C. laviusculus], B. crenatus] }\end{array}$ \\
\hline 126 & 1983 & [Bougainvillia sp. \\
\hline 127 & 1982 & $\begin{array}{l}\text { [Bougainvillia sp., O. longissima] } \\
\text { I. phosporea], [Bougainvillia sp. }\end{array}$ \\
\hline 129 & 1985 & H. arctica], M. edulis] \\
\hline \multicolumn{3}{|l|}{ Niodeí 3} \\
\hline 172 & 1983 & [B. crenatus, Bougainvillia sp.] \\
\hline 158 & 1985 & {$[M$. edulis, $[B$. crenatus } \\
\hline 100 & 1977 & [O. longissima, $[H$. arctica, $[M$. edulis \\
\hline 101 & $\begin{array}{l}1980 \\
1981 \\
1983 \\
1984 \\
1985\end{array}$ & 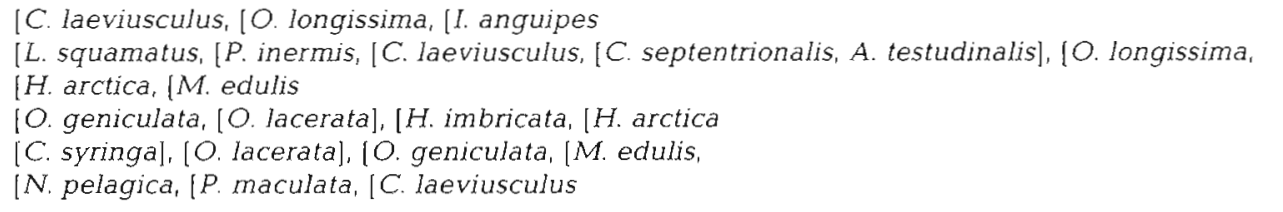 \\
\hline 69 & 1975 & [L. squamatus, [I. anguipes, [H. arctica \\
\hline 68 & 1976 & [S. balanoides, [H. arctica, [M. edulis \\
\hline 63 & $\begin{array}{l}1975 \\
1977\end{array}$ & $\begin{array}{l}\text { A. vulgaris, }[\text { S. balanoides } \\
\text { |P. maculata, [T. larynx }\end{array}$ \\
\hline 66 & 1984 & {$[P$. inermis], [S. droebachiensis, [S. balanoides, $[T$. larynx, [L. vincta, C. septentrionalis $]$} \\
\hline 54 & 1983 & [S. droebachiensis \\
\hline
\end{tabular}

6 show a complex fluctuating pattern where the ranges of species distribution expand or shrink from one year to another, but where the major discontinuities at intermediate and large spatial scales are, however, distinctly defined. To better visualize these results, discontinuities observed at neighbouring stations (neighbours at a scale of tens of kilometres) were grouped so that only the stations or groups of stations where the major discontinuities occurred across the years were highlighted. These were: Model 1, Stns 6 to 8 , 14 to 23,25 to 43,69 to 68,66 to 60,57 to 54 ; Model 2, Stns 6 to 8,14 to 23,25 to 43,73 to 78,83 to 84,90 to 93 , 121 to 129 ; Model 3, Stns $172,158,100$ to 101,69 to 68 , 66 to 63,54 (Fig. 6).

\section{DISCUSSION}

The invertebrate fauna observed on the buoys was mostly composed of intertidal and sublittoral marine and estuarine species. This fauna is characteristic of the northwestern Atlantic area and includes species whose distributions range from the Arctic Ocean to the Gulf of México. As in most typical estuarine environments (Remane \& Schlieper 1971), the number of species diminished steadily following the decreasing salinity gradient. However, few freshwater species were found in the brackish portion of the system and no increase in richness of these forms was observed going up in the direction of the Fluvial Estuary. 


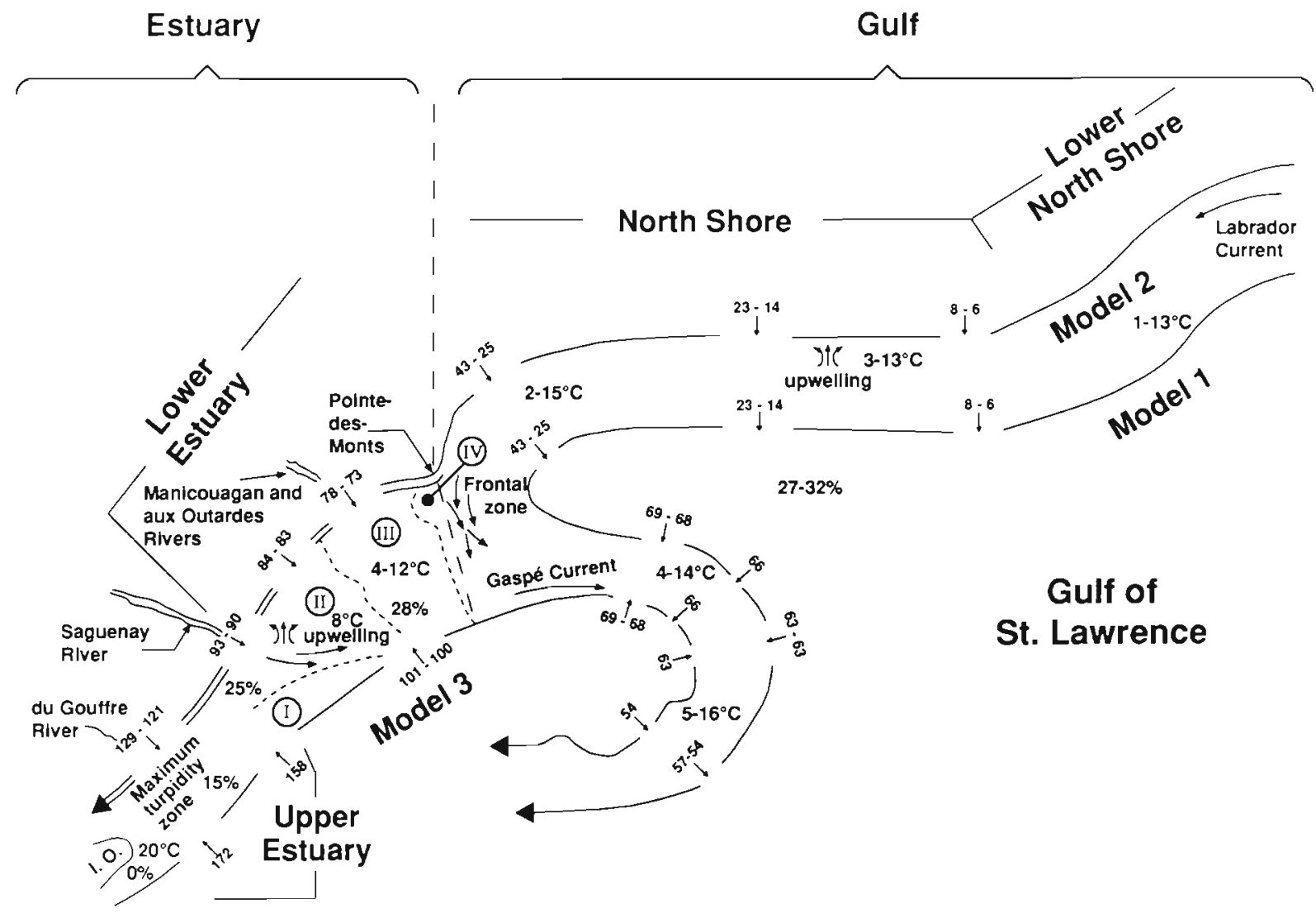

Fig. 6. Discontinuities in species distribution observed along the 3 lines (models) of larval dispersion considered. Arrows perpendicular to the paths of larval dispersal, and associated numbers (stations or groups of stations), summarize the regions of major discontinuities observed across the years; dashed lines and Areas I to IV indicate divisions of the Lower Estuary defined on the basis of hydrographic and primary production characteristics (modified from Therriault \& Levasseur 1985)

\section{Distributional relations of species}

In spite of the large size and physical heterogeneity of the study area (Dickie \& Trites 1983, El-Sabh \& Silverberg 1990), the yearly analyses of species associations conducted at different spatial scales showed the same basic group of species throughout the overall EstuaryGulf system. This group consisted of some 'foundation' species (Sutherland 1981, Dayton 1984) of hard-bottom substrata: the hydroid Obelia longissima, the bivalves Hiatella arctica and Mytilus edulis, and the cirripedes Semibalanus balanoides and Balanus crenatus. It also included some associated motile taxa, particularly Lacuna vincta, one unidentified nudibranch species, Lepidonotus squamatus, Nereis pelagica, Phyllodoce maculata, Ischyrocerus anguipes, and Calliopius laeviusculus.

The species grouping together on a recurrent basis are assumed to share common ecological traits and to respond in a related way to the properties of the environment (Fager \& McGowan 1963, Legendre \& Legendre 1978). Here, these species share (1) a planktotrophic pelagic development, (2) the ability to main- tain themselves in the upper layer of the water column during the larval phase prior to settlement, and (3) the capacity to live continuously immersed during the adult phase. Furthermore, these species are under the direct influence of the environmental conditions prevailing in the surface water layer (e.g. temperature, salinity, turbidity, turbulence, water currents, and quality and quantity of food).

The occurrence of such a widespread and recurrent association does not imply that the overall epibenthic fauna behaves as an homogeneous entity. Only some species were highly coincident in their spatial distribution and were always members of the group. The boundaries of the association were diffuse and fluctuated from year to year, especially at the head of the estuary. When species distributions were mapped together (Table 2), it was apparent that the geographic ranges of the different species varied greatly. This variability probably reflects a spectrum of adaptive abilities allowing species to make use of different parts of the habitat and to adjust their range of distribution to the environmental changes. 


\section{Spatial discontinuities in distribution}

Analytical approach

Patterns of species distribution may be described by defining ecological series of sampling sites along natural gradients of environmental change. In our study, the residual circulation patterns were assumed to reflect the major axes of species dispersion along the gulf and estuarine gradients. This is, however, a simplification since other dispersal patterns may also exist. No assumptions were made here regarding the swimming behaviour and vertical migration of larvae into the water column. Instead, it was inferred that larvae could be transported from one part of the system to another For instance, the first model of species dispersal (Model 1) assumed that the larvae released along the Lower North Shore, the North Shore, and the Gaspé coast could be carried along by the dominant currents observed in the area. These dispersal models should not be interpreted as suggesting that larvae drift from the Strait of Belle-Isle to the Gaspé coast (Model 1) or to the Saguenay Fjord (Model 2) within a year, but rather as showing the potential corridors along which larvae could move in time to colonize favorable areas. In nature, the probability of longdistance larval transport is rather reduced. Indeed (1) for most species the duration of the larval development is too short, (2) the harsh and fluctuating environmental conditions may induce high larval mortality, and (3) the current patterns are variable both spatially and temporally (Scheltema 1982, Johannesson 1988). Accurate estimations of the distance travelled by larvae must be based on a comprehensive knowledge of the surface and subsurface circulation patterns. Published data on current variability in the study area are at best fragmentary when not contradictory (ElSabh 1976, Gregory et al. 1989, Koutitonsky \& Bugden 1991). Considering that the benthic fauna generally occur in discrete patches, the presence of migrants into the water mass was probably due to parent populations distributed at several points along the littoral Thus, the larvae reaching the buoys could be released at any undetermined distance somewhere 'upstream' from the sites where they settled. In this context, the changes in species distribution observed across the years could be the result of demographic and environmental stochasticity affecting both the parent populations and the migrants carried by the currents.

The spatial discontinuities (Fig. 5) were the byproduct of the heterogeneous distribution of all the species recorded along the lines of contiguous collectors. However, only the species whose first ('beginning') and last ('end') presence on the lines were statistically significant (Table 6) could be clearly asso- ciated with each specific discontinuity. Given the high yearly variability in the distribution ranges of species, grouping together the neighbouring stations allowed us to better visualize the limits of distribution on an interannual basis. Thus, for example, the discontinuity formed by Stns 121 to 129, located in the Upper Estuary between Île d'Orléans and Île-aux-Coudres (Fig. 6), could be better associated with the distributional limits of Idothea phosphorea, Calliopius laeviusculus, Obelia longissima, Hiatella arctica, Mytilus edulis, and Balanus crenatus. In a similar way, the discontinuity represented by Stns 100 to 101, located on the south shore of the Lower Estuary, marked in a more perceptible way the limits of penetration of Lepidonotus squamatus, Nereis pelagica, and Pontogeneia inermis into the Estuary waters during the overall period of study.

Factors limiting species distribution

Regional differences in salinity, temperature, water column stability: larval advection, and food particle size spectrum could be expected to explain the observed patterns in species distribution. Such an explanation, to be satisfactory, should also include the behavioural patterns and ecological preferences of species at different stages of their life history. Thus, for instance, it has been shown that the feeding behaviour and the feeding effectiveness of hydroids vary with the species and the physical conditions of the environment (Marfenin 1981, Hunter 1989). However, in the absence of simultaneous field surveys of these factors and the dispersal dynamics of the benthic fauna, specific relationships between a factor or group of factors and the patterns of distribution of particular species remain speculative.

Even though, at this stage, definite causal relationships cannot be established, major discontinuities in species distribution (Fig. 6) were observed in areas where changes in well-defined physical features of the system do occur. The exact locations of discontinuities vary from year to year, presumably because local or regional hydrographical conditions also vary from year to year. The most outstanding are the following:

Discontinuities near Stns 6 to 8. This zone of discontinuities is located near the Strait of Belle-Isle, the coldest region of the system. Here, summer surface temperatures range from 1 to $13^{\circ} \mathrm{C}$ (Vigeant 1987 . Petrie 1990). This zone marks the transition between the North Shore region, under the influence of the Gulf conditions (Koutitonsky \& Bugden 1991), and the region directly influenced by the Labrador Current. Steven (1974) described the latter as being the least 
productive of the whole Estuary-Gulf system. Two species were observed exclusively in this zone: Hyas sp. and Lepas anatifera.

Discontinuities near Stns 14 to 23. The low temperatures observed all along the North Shore region in the summer suggest that upwelling occurs all along the coast (D. Lefaivre, Maurice Lamontagne Institute, pers. comm.). However, studies by Lauzier et al. (1957) suggest that the upwelling in the Mingan region is quasi-permanent during summer. We hypothesize that, in this area, the combined effects of local bathymetry on surface circulation as well as upwelling of cold $\left(3\right.$ to $\left.6{ }^{\circ} \mathrm{C}\right)$ waters, induced presumably by northwest winds and tidal mixing of cold intermediate waters with warmer surface waters (Lauzier et al. 1957), are responsible for the limits observed there. Hydrographically, this region is also unique on the North Shore in showing higher content of seston particles in the water column than surrounding areas (Nota \& Loring 1964). Doto coronata, Margarites helicinus, Lepidonotus squamatus, and Strongylocentrotus droebachiensis began their distributional range on the buoys of the Lower North Shore/North Shore in the Mingan region, and Clytia hemisphaerica, present along the Strait of Belle-Isle, ended its distributional range there.

Discontinuities near Stns 25 to 43. This zone of discontinuities marks the limit between the Gulf and Estuary. It is physically characterized by a frontal zone formed by the cyclonic Anticosti gyre and the southerly transverse current at Pointe-des-Monts (10 to $40 \mathrm{~cm} \mathrm{~s}^{-1}$; El-Sabh $1977 \mathrm{~b}$ ) which might constitute a physical barrier to the westward transport of surfacedrifting larvae. Presumably, the latter could be advected by the surface-flushing circulation prevailing in this area. Another obstacle to the transport of larvae from the north shore of the Gulf to the Estuary is associated with salinity differences (as high as $6 \%$ ) from one side of the frontal zone to the other (Petrie 1990). The discontinuities also delimit a region of relatively high estuarine sestonic content from the lower sestonic load of the Gulf water (Nota \& Loring 1964). Among the marine species whose distributional limits are located at the mouth of the Estuary are Gammarellus angulosus, G. homari, and Anomia aculeata

Discontinuities near Stns 69 to 68 . The zone where these discontinuities occur is strongly influenced by the Gaspé Current and also by the transverse current flowing from the north to the south shore of the Estuary where it merges with the Gaspé Current. Again, the transverse current may act as an hydrodynamical barrier to the larvae. Presumably, larvae entering the Gaspé Current are advected eastward to the open Gulf. As an example, the ophiuroid Ophiura robusta was present on the buoys moored along the western North Shore and northern Gaspé Peninsula. but was not observed on the buoys located within the Estuary

Discontinuity near Stn 66. This discontinuity separates the stations north of the Baie de Gaspé from those of the Bay itself. Because of the topography of the Gaspé Peninsula, the former are directly influenced by the Gaspé Current while the latter are enclosed in a local estuarine system. Metopa sp. and Sertularia cupressina ended their distributional range along the North Shore and Gaspé Peninsula coast at Stn 66. Gammarus oceanicus and Mya arenaria extended their range to stations located inside the Baie de Gaspé.

Discontinuity near Stn 60. Stations situated south of Stn 60 down to Stn 54 are little influenced by the Gaspé Current, while at the same time not being quite under the physical influence of Baie des Chaleurs. These stations are located somewhat in a transitional region between these 2 areas.

Discontinuities near Stns 57 to 54. These discontinuities are located at the mouth of Baie des Chaleurs. They mark clearly the junction between the warm, semi-enclosed shallow system of Baie des Chaleurs and the more exposed stations located northwards. Three species - Harmothoe extenuata, Jassa falcata, and Opercularella lacerata - met their distributional limits along the Gaspé coast in this area.

Discontinuities near Stns 73 to 78. This zone coincides with the mouth of the Manicouagan and aux Outardes rivers, a system whose mean annual freshwater discharge is about $800 \mathrm{~m}^{3} \mathrm{~s}^{-1}$. These discontinuities mark the limit of penetration into the Estuary of Lepidonotus squamatus, Jassa falcata, Strongylocentrotus droebachiensis, Tubularia larynx, and Mya arenaria.

Discontinuities near Stns 83 and 84 . The region delimited by Stns 83 and 84 up to the Saguenay River is directly influenced by the upwelling of cold intermediate waters (Ingram 1979. Therriault \& Levasseur 1985). These discontinuities mark the limit of penetration along the north shore of the Estuary for Nereis pelagica and Pontogeneia inermis.

Discontinuities near Stns 90 to 93. These discontinuities correspond to the current outflow of the Saguenay River, the most important single tributary of the St. Lawrence Estuary (mean annual runoff of $1800 \mathrm{~m}^{3} \mathrm{~s}^{-1}$ ). The strong (30 to $50 \mathrm{~cm} \mathrm{~s}^{-1}$ ) transverse current associated with this hydrodynamical feature (El-Sabh 1977b) probably creates a barrier for the penetration of larvae and causes direct advection of particles eastward and towards the south shore. This zone marks the limit of penetration into the Estuary of Caprella septentrionalis, Ischyrocerus anguipes, Obelia geniculata, Semibalanus balanoides, and an unidentified nudibranch species. 
Discontinuities near Stns 121 to 129. These discontinuities correspond to the north shore limit of the zone of maximum turbidity, as well as to the outer limit of the maximum salinity gradient ( 0 to $18 \%$ ) of the Upper Estuary (Kranck 1979, Lucotte \& d'Anglejan 1986). The area where these discontinuities occur is also under the direct influence of the freshwater outflow of rivière du Gouffre (mean annual runoff $21 \mathrm{~m}^{3} \mathrm{~s}^{-1}$ ), representing an additional source of osmotic stress for the organisms. It is also a region of upwelling of waters from the Lower Estuary penetrating in the Upper Estuary. These discontinuities mark the limit of penetration, along the north shore of the Estuary, of the following species: Idothea phosphorea, Calliopius laeviusculus, Obelia longissima, Hiatella arctica, Mytilus edulis, and Balanus crenatus.

Discontinuities at Stns 100 and 101. These discontinuities are difficult to explain on the basis of local conditions as no major apparent changes in physiographical or hydrographical features are distinguishable in this area. According to Therriault \& Levasseur (1985) the area where these discontinuities occur is under the influence of the Manicouagan and aux Outardes plume, which influence, presumably, the physical conditions even near the south shore of the Estuary. Hydrographically, this area is more stable than adjoining ones due to the freshwater input and the mitigated effects of tidal mixing. These discontinuities mark the limit of penetration, along the south shore of the Estuary, of Lepidonotus squamatus, Nereis pelagica, and Pontogeneia inermis.

Discontinuity near Stn 158. Roughly, this discontinuity corresponds to the limit between the Lower and Upper Estuary on the south shore. These 2 bodies of water differ obviously by their suspended seston load and salinity gradient, abrupt in the Upper Estuary and weak in the Lower Estuary. Presumably, the shallow water on the south shore of the Estuary westward of Stn 158, together with numerous small and medium-size rivers, impose a fluctuating salinity regime detrimental to the marine species.

Discontinuity near Stn 172. This discontinuity marks the westward limit of saltwater penetrating along the south shore. It also marks the limit of penetration into the Upper Estuary of the hydroid Bougainvillia sp.

Thus, the epibenthic species discontinuities are nearly always associated with major traits of the physical environment. These are either physiographical features which induce major hydrographical changes (e.g. entrance of Strait of Belle-Isle, Pointe-des-Monts coastline, Cape Gaspé), hydrodynamic factors associated with major localized freshwater inputs (e.g. Manicouagan/aux Outardes rivers, Saguenay Fjord), hydrodynamic singularities (e.g. Mingan and Laurentian Channel head upwellings, density and turbidity fronts), or surface circulation patterns (e.g. estuarine transverse currents, Anticosti gyre, Gaspé Current). Some of the species discontinuities shown in this study correspond fairly well to ecological limits reported in previous biogeographical studies. Thus, for instance, discontinuities near Stns 121 to 129 and 158 correspond together to the limits separating the medium and highly brackish subregions proposed by Bousfield (1956) and Dunbar et al. (1980) for the Upper Estuary. Similarly, discontinuities near Stns 93 to 90,84 to 83,78 to 73 , and 101 to 100 (Fig. 6) correspond to the ecological divisions proposed by Therriault \& Levasseur (1985) for the Lower Estuary on the basis of phytoplankton biomass and production. While the former investigators divided the study area on the basis of ecological characteristics of the littoral fauna, the latter ones divided it on the basis of ecological characteristics of the phytoplankton community. Ardisson et al. (1990), by analysing the spatio-temporal changes in the community structure of biomass of the dominant epibenthic species of the St. Lawrence system, distinguished 6 broad biogeographical zones whose limits closely reflert those observed in this study, particularly within the Gulf area.

The above discussion clearly shows that important gaps exist in our knowledge of both physical coastal processes and dispersal and survival of benthic larval populations in this system. Our study identifies, however, a number of transitional areas where welldefined changes in the physical or biological properties of the environment occur, pointing out several critical regions where future work could be conducted on larval dispersal and survival of newly settled spat. The factors which determine the location and temporal variation of the species discontinuities observed here must be elucidated if the actual distribution patterns of these species are to be understood. Particular attention should be paid to the influence of different hydrodynamical forces and behavioural mechanisms on drift and larval dispersal, and this at intermediate and small spatial scales.

Acknowledgements. We thank S. Fugulin for her help in the field and laboratory work, Drs J. Boulva and J.-C. Therriault from Institut Maurice-Lamontagne, Fisheries and Oceans Canada, for their encouragement, and Transport Canada for their assistance and understanding throughout the period of study. Thanks are also due to Dr Dale Calder, Royal Ontario Museum, for identifying the hydroids, Prof. Michel Godron, Université des Sciences et Techniques du Languedoc, Montpellier, for his aid with the binary data analyses, Dr Pierre Morisset, Université Laval, and 3 anonymous reviewers for criticizing the manuscript. Financial support was provided by grants from NSERC and FCAR to E. Bourget and a scholarship from the Ministère de l'Enseignement Supérieur et de la Science du Québec to P.-L.A. 


\section{LITERATURE CITED}

Ardisson, P.-L., Bourget, E. (1991). Abundance, growth, and production estimation of the blue mussel Mytilus edulis on moored navigation buoys in the Estuary and northwestern Gulf of St. Lawrence. Can. J. Fish. Aquat. Sci. 42: 2408-2419

Ardisson, P.-L., Bourget, E., Legendre, P. (1990). Multivariate approach to study species assemblages at large spatiotemporal scales: the community structure of the epibenthic fauna of the Estuary and Gulf of St. Lawrence. Can. J. Fish. Aquat. Sci. 47: 1364-1377

Banks, R. E. (1966). The cold layer in the Gulf of St. Lawrence. J. geophys. Res. 71: 1603-1610

Benoit, J., El-Sabh, M. I., Tang, C. L. (1985). Structure and seasonal characteristics of the Gaspé Current. J. geophys. Res. 90: 3225-3236

Bousfield, E. L. (1956). Studies on the shore fauna of the St. Lawrence Estuary and Gaspé coast. Bull. nat. Mus. Can. 136: $95-101$

Brunel, P. (1970). Les grandes divisions du Saint-Laurent. Revue Géogr. Montréal 24: 291-294

Bugden, G. L. (1981). Salt and heat budgets for the Gulf of St. Lawrence. Can. J. Fish. Aquat. Sci. 38: 1153-1167

Dayton, P. K. (1984). Processes structuring some marine communities: are they general? In: Strong, D. R. Jr, Simberloff, D., Abele, L. G., Thistle, A. B. (eds.) Ecological communities: conceptual issues and the evidence. Princeton University Press, Princeton, p. 181-197

Dickie, L. M., Trites, R. W. (1983). The Gulf of St. Lawrence In: Ketchum, B. H. (ed.) Estuaries and enclosed seas. Elsevier, Amsterdam, p. 403-425

Dunbar, M. J., Maclellan, D. C., Filion, A., Moore, D. (1980). The biogeographic structure of the Gulf of St. Lawrence. Marine Sciences Centre MS Rep. 32, McGill Univ. Montréal

El-Sabh, M. I. (1976). Surface circulation pattern in the Gulf of St. Lawrence. J. Fish. Res. Bd Can. 33: 124-138

El-Sabh, M. I. (1977a). Oceanographic features, currents, and transport in Cabot Strait. J. Fish. Res. Bd Can. 34: $516-528$

El-Sabh, M. I. (1977b). Circulation pattern and water characteristics in the Lower St. Lawrence Estuary. In: Murty, T.S. (ed.) Symposium on Modelling of Transport Mechanisms in Oceans and Lakes. Man. Rep. Ser. 43 Marine Sciences Directorate, Fisheries and Environment, Burlington, Ontario, p. 243-248

El-Sabh, M. I. (1979). The Lower St. Lawrence Estuary as a physical oceanographic system. Naturaliste can. (Rev. Ecol. Syst.) 106: 55-73

El-Sabh, M. I., Lie, H.-J., Koutitonsky, V. G. (1982), Variability of the near-surface residual current in the Lower St Lawrence Estuary. J. geophys. Res. 87: 9589-9600

El-Sabh, M. I., Silverberg, N. (eds.) (1990). Oceanography of a large-scale estuarine system: the St. Lawrence. SpringerVerlag, New York

Fager, E. W., McGowan, J. A. (1963). Zooplankton species groups in the North Pacific. Science 140: 453-460

Forman, R. T. T., Godron, M. (1986). Landscape ecology. Wiley, New York

Fradette, P., Bourget, E. (1980). Ecology of benthic epifauna of the Estuary and Gulf of St. Lawrence: factors influencing their distribution and abundance on buoys. Can. J. Fish. Aquat. Sci. 37: 979-999

Fradette, P., Bourget, E. (1981). Groupement et ordination appliqués à l'étude de la répartition de l'épifaune benthique de l'estuaire maritime et du golfe du Saint-Laurent. J. exp. mar. Biol. Ecol. 50: 133-152
Gauthier, B., Godron, M. (1976). La recherche de limites ou de coupures optimales; application à un relevé phytosociologique. Naturaliste can. (Rev. Écol. Syst.) 103: $203-214$

Godron, M. (1966). Application de la théorie de l'information à l'étude de l'homogénéité et de la structure de la végétation. Oecol. Plant. 3: 185-212

Godron, M., Bacou, A.-M. (1975). Sur les limites 'optimales' séparant deux parties d'une biocénose hétérogène. Ann Univ. Abidjan Sér. E 8: 317-324

Gregory, D. N., Nadeau, O. C., Lefaivre, D. (1989). Current statistics of the Gulf of St. Lawrence and Estuary. Can. Tech. Rep. Hydrogr. Ocean Sci. 120

Hunter, T (1989). Suspension feeding in oscillating flow: the effect of colony morphology and flow regime on plankton capture by the hydroid Obelia longissima. Biol. Bull. 176 $41-49$

Ingram, R. G. (1979). Water mass modification in the St. Lawrence Estuary. Naturaliste can. (Rev. Écol. Syst.) 106: 45-54

Johannesson, K. (1988). The paradox of Rockall: why is a brooding gastropod (Littorina saxatilis) more widespread than one having a planktonic larval dispersal stage (L. littorea)? Mar. Biol. 99: 507-513

Kinne, O. (1970). Salinity. Animals - Invertebrates. In: Kinne, O. (ed.) Marine ecology, Vol. I, part 1. Wiley-Interscience, London, p. 821-995

Koutitonsky, V. G., Bugden, G. L. (1991). The physical oceanography of the Gulf of St. Lawrence: a review with emphasis on the synoptic variability of the motion. In Therriault J.-C. (ed.) The Gulf of St. Lawrence: small ocean or big estuary? Can. Spec. Publ. Fish. Aquat. Sci 113: $57-90$

Kranck, K. (1979). Dynamics and distribution of suspended particulate matter in the St. Lawrence Estuary. Naturaliste can. (Rev. Écol. Syst.) 106: 163-173

Krylov, B. V. (1968). Species association in plankton. Oceanology (English translation from Okeanologiya) 8: 243-251

Lacroix, J., El-Sabh, M. I., Condal, A., Dubois, J. M. M. (1985). Structure thermique et variabilité du courant de surface dans l'estuaire et le golfe du Saint-Laurent à l'aide d'images du satellite NOAA-7. In: Bernier, M., Lessard G., Gagnon, P. (eds.) Télédétection et gestion des ressources: l'aspect opérationnel, Vol 5. L'association Québécoise de Télédétection, Québec, p. 435-444

Lauzier, L., Trites, R. W., Hachey, H. B. (1957). Some features of the surface layer of the Gulf of St. Lawrence. Bull. Fish. Res. Bd Can. 111: 195-212

Lavoie, R. (1970). Contribution à la biologie et à l'écologie de Macoma balthica L. de l'estuaire du Saint-Laurent. Thèse de doctorat, Université Laval, Québec

Legendre, L., Legendre, P. (1978). Associations. In: Sournia, A. (ed.) Phytoplankton manual. UNESCO, Paris, p. $261-272$

Legendre, L., Legendre, P. (1984). Ecologie numérique 2. La structure des données écologiques, 2nd edn. Collection d'écologie 13. Masson, Paris, et les Presses de l'Université du Québec

Lucotte, M., d'Anglejan, B. (1986). Seasonal control of the Saint-Lawrence maximum turbidity zone by tidal-flat sedimentation. Estuaries 9: 84-94

Mann, R. (1986a). Arctica islandica (Linné) larvae: active depth regulators or passive particles. Am. mala. Bull. Spec. Publ. 3: 51-57

Mann, R (1986b). Sampling of bivalve larvae. In: Jamieson, G. S., Bourne, N. (eds.) North Pacific workshop on stock assessment and management of invertebrates. Can. Spec. Pub. Fish. Aquat. Sci. 92: 107-116 
Marfenin, N. N. (1981). Some peculiarities of digestion in the hydranths of different colonial hydroids. Zh. obshch. Biol. 42: $399-408$

Menge, B. A., Sutherland, J. P. (1987). Community regulation: variation in disturbance, competition, and predation in relation to environmental stress and recruitment. Am. Nat. 130: $730-757$

Mertz, G., El-Sabh, M. I., Koutitonsky, V. G. (1988). Winddriven motions at the mouth of the Lower St. Lawrence Estuary. Atmosphere-Ocean 26: 509-523

Mertz, G., El-Sabh, M. I., Koutitonsky, V. G. (1989). Low frequency variability in the Lower St. Lawrence Estuary. J. mar. Res. 47: 285-302

Neu, H. J. A. (1970). A study on mixing and circulation in the St. Lawrence Estuary up to 1964. Rep. Ser. 1970-9, Atlan. Oceanogr. Lab., Bedford Inst., Dartmouth, N.S.

Nota, D. J G., Loring, D. H. (1964). Recent depositional conditions in the St. Lawrence River and Gulf - A reconnaissance survey. Mar. Geol. 2: 198-235

Petrie, B. (1990). Monthly means of temperature, salinity and sigma-t for the Gulf of St. Lawrence. Can. Tech. Rep. Hydrogr. Ocean Sci.

Petrie, B., Toulany, B., Garrett, C. (1988). The transport of water, heat and salt through the Strait of Belle Isle. Atmosphere-Ocean 26: 234-251

Possingham, H. P., Roughgarden, J. (1990). Spatial population dynamics of a marine organism with a complex life cycle. Ecology 71 : $973-385$

Remane, A., Schlieper, C. (1971). Biology of brackish water. Wiley-Interscience, New York

Rohlf, F. J. (1963). Classification of Aedes by numerical taxonomic methods (Diptera: Culicidae). Ann. ent. Soc. Am. 56: 798-804

This article was submitted to the editor
Sanders, H. L. (1968). Marine benthic diversity: a comparative study. Am. Nat. 102: 243-282

Scheltema, R. S. (1982). Dispersal of pelagic larvae and the zoogeography of tertiary marine benthic gastropods. In Gray, J., Boucot, A. J. (eds.) Historical biogeography, plate tectonics, and the changing environment. Oregon State University Press, Corvallis, p. 391-397

Southward, A. J. (1967). Life on the sea-shore. Harvard University Press, Cambridge

Steven, D. M. (1974). Primary and secondary production in the Gulf of St. Lawrence. Marine Sciences Centre MS Rep. 26. McGill Univ., Montréal

Sutherland, J. P. (1981). The fouling community at Beaufort, North Carolina: a study in stability. Am. Nat. 118:499-519

Therriault, J.-C., Levasseur, M. (1985). Control of phytoplankton production in the Lower St. Lawrence Estuary: light and freshwater runoff. Naturaliste can. (Rev. Écol. Syst.) 112: 77-96

Underwood, A. J., Denley, E. J. (1984). Paradigms, explanations, and generalizations in models for the structure of intertidal communities on rocky shores. In: Strong, D. R. Jr, Simberloff, D., Abele, L. G., Thistle, A. B. (eds.) Ecological communities: conceptual issues and the evidence. Princeton University, Princeton, p. 151-180

Venrick, E. L. (1971). Recurrent groups of diatom species in the North Pacific. Ecology 52: 614-625

Vigeant, G. (1987). Température mensuelle de l'eau en surface dâns l'estuaire et le golfe du Saint-Laurent. Service de l'environnement atmosphérique, Région Québec, Environment Canada, Ottawa

Wolff, W. J. (1983). Estuarine benthos. In: Ketchum (ed.) Estuaries and enclosed seas. Elsevier, Amsterdam, p $151-182$

Manuscript first received: June 27, 1991

Revised version accepted: April 22, 1992 